\title{
Differential Response: A Dangerous Experiment in Child Welfare
}

\section{Citation}

Elizabeth Bartholet, Differential Response: A Dangerous Experiment in Child Welfare, 42 Fla. St. U. L. Rev. 573 (2015).

\section{Permanent link}

http://nrs.harvard.edu/urn-3:HUL.InstRepos:12694222

\section{Terms of Use}

This article was downloaded from Harvard University's DASH repository, and is made available under the terms and conditions applicable to Other Posted Material, as set forth at http:// nrs.harvard.edu/urn-3:HUL.InstRepos:dash.current.terms-of-use\#LAA

\section{Share Your Story}

The Harvard community has made this article openly available.

Please share how this access benefits you. Submit a story.

\section{Accessibility}




\title{
DIFFERENTIAL RESPONSE: A DANGEROUS EXPERIMENT IN CHILD WELFARE
}

\author{
ELIZABETH BARTHOLET ${ }^{*}$
}

\begin{abstract}
Differential Response represents the most important child welfare initiative of the day, with Differential Response programs rapidly expanding throughout the country. It is designed to radically change our child welfare system, diverting the great majority of Child Protective Services cases to an entirely voluntary system. This Article describes the serious risks Differential Response poses for children and the flawed research being used to promote it as "evidence based." It puts the Differential Response movement in historical context as one of a series of extreme family preservation movements supported by a corrupt merger of advocacy with research. It argues for reform that would honor children's rights, confront the problems of poverty underlying child maltreatment in a serious way, and expand rather than reduce the capacity of Child Protective Services to address child maltreatment. It calls for a change in the dynamics of child welfare research and policy so that we can avoid endlessly repeating history in ways harmful to child interests.
\end{abstract}

INTRODUCTION 574

I. Prior History: Extreme Family Preservation Movements Supported BY ADVOCACY RESEARCH

A. Intensive Family Preservation Services...

582

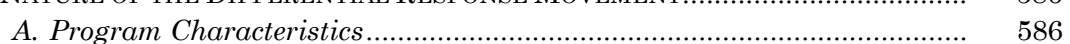

1. The Diversion Goal .......................................................................... 586

2. Voluntary, Not Coercive .............................................................. 587

3. No Fact-Finding Investigation and No Maltreatment Findings ........ 589

4. Financial Support Emphasized over Rehabilitative Services ............. 590

B. Related Finance "Reform ".................................................................... 590

III. Risks to CHILDREn PoSED By DIFFERENTIAL RESPONSE .............................. 593

A. Risks to Children in the Current System ................................................. 593

B. New Risks From Differential Response .............................................. 598

1. Risks from Diversion to Voluntary Track ....................................... 598

(a) Serious Risk Cases on the Voluntary Track.............................. 598

i. Diverted Cases are Serious Risk by Definition Given Nature of CPS Caseload .............................................................. 598

ii. Absence of Investigation Means No Ability to Identify Which Cases Are Serious Versus Minor.....

599

iii. Evidence to Date Indicates Serious Risk Cases Are in Fact Diverted to the Voluntary Track.....

(b) Voluntary Track Inappropriate for Serious Risk Cases...............

i. Need for Monitoring, Supportive and Rehabilitative Services, and for Protective Intervention Authority.

ii. The Dropout Problem: Highest Risk Cases Most Likely to Drop Out

* Elizabeth Bartholet is a Professor of Law at Harvard Law School and Faculty Director of its Child Advocacy Program. For her various publications on child welfare issues, see http://www.law.harvard.edu/faculty/bartholet/pubs.php. For their helpful comments, thanks to James G. Dwyer, Daniel Heimpel, Ronald Hughes, Kathryn A. Piper, Judith Rycus, and Frank Vandervort. Thanks also to Daniel Heimpel for his helpful investigation of the issues and to Noah Dzuba, Sean Hughes, and Tim Morrison for their assistance in that investigation and their research and policy analysis. Thanks finally to Harvard Law School student David J. Hotelling for his excellent research assistance. 
2. Risks From Reducing Financial Support for Traditional CPS.

IV. Research Issues in Differential Response: The CorRupt Merger of ADVOCACY WITH RESEARCH.

A. What Child-Friendly Research Would Look Like......

B. Existing Research .....

1. The Early Advocacy Research......

(a) Promotional Nature \& Tone......

(b) Parent Satisfaction as Measure of Success

(c) Parent Engagement Claims ................................................... 616

(d) Child Safety Claims ............................................................... 617

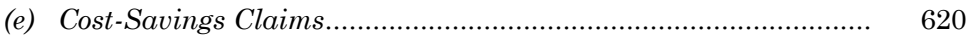

2. The Independent Research ................................................................... 620

3. Hughes and Rycus Analysis of the Early Advocacy Research ............ 623

4. The QIC-DR Research ................................................................ 626

(a) New Evidence of Safety Risks in Differential Response.............. 628

i. High Re-Report Rates on the Voluntary Track ....................... 628

ii. High Drop-Out Rates and Related Safety Risks on the Voluntary Track

629

(b) Continuation of the Advocacy Research Mode ............................. 630

V. The Underlying Politics: Why the Resistance to Child-Friendly CHILd Welfare Policies?

A. Children Have No Rights.....

$B$. The Left-Right Bargain: A Cheap Version of the War on Poverty ...

C. Private Wealth Dominance over Policy Advocacy and Research

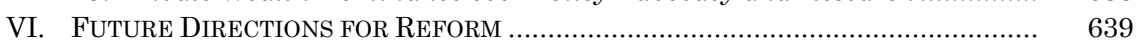

A. Children's Rights ............................................................................ 639

B. Maltreatment Prevention: Radical Social Reform, Early Supportive

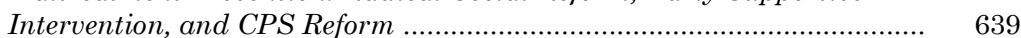

C. Research Reform .......................................................................... 641

CONCLUSION ……....................................................................... 642

\section{INTRODUCTION}

A powerful coalition of forces is pushing our nation's child welfare system toward a "reform" they generally call Differential Response (DR). The idea is to divert the vast majority of cases now dealt with by child protective services (CPS) to an entirely voluntary system that leaves parents free to refuse to participate without fear of any consequence.

Other names for DR systems include Alternative Response (AR), Family Assessment Response, Dual-Track, Multi-Track, or MultipleResponse Systems, and in an earlier era, Community Partnership. ${ }^{1}$ $\mathrm{DR}$ is often used to refer to the overall system that includes two

1. I discuss Community Partnerships in my 1999 book, Nobody's Children. ELIZABETH BARTHOLET, NOBODY's CHILDREN 146-54 (1999). DR was first implemented in Missouri and Florida between 1993 and 1995. Alan Puckett, Casey Family Programs, Differential Response: Review and Summary of Research Evidence, UNIV. OF COLO. DENVER (Oct. 25, 2013), http://www.ucdenver.edu/academics/colleges/medicalschool/departments/ pediatrics/subs/can/DR/Documents/Conference\%202013\%20Handouts/Friday/DR\%20Review \%20and\%20Summary\%20of\%20Research\%20Evidence.pdf (last visited July 20, 2014), archived at http://perma.cc/7D8W-F2GJ. 
tracks-one, the new AR Track, and the other, the traditional CPS track. $^{2}$ Some systems have a third track for cases which would normally be screened out by CPS based on a conclusion that there is no apparent need for CPS intervention to protect children. ${ }^{3}$ I will use DR to refer to the overall system and will use AR and Traditional Response (TR) to refer to the two tracks used for cases that normally would be screened in by CPS.

DR constitutes the latest fad in extreme forms of family preservation promoted over recent decades. ${ }^{4}$ It is expanding rapidly throughout the country. ${ }^{5}$ One comprehensive analysis of DR notes that the "development of a national advocacy team and access to significant federal and foundation resources" make DR "one of the more widely replicated child welfare reform efforts in recent history." ${ }^{6}$ An important 2014 Report summarizing recent research indicates that DR has already been implemented in a majority of states. ${ }^{7}$ The federal

2. For DR history, descriptions, and definitions, see generally INST. OF MED. \& NAT'L Research Council, New Directions in Child Abuse and Neglect Research 198-99, 203-04 (Anne C. Peterson et al. eds., 2014) [hereinafter IOM/NRC 2014 REPORT], available at http://www.iom.edu/Reports/2013/New-Directions-in-Child-Abuse-and-Neglect-Research. aspx, archived at http://perma.cc/8DSZ-FR79; TAMARA FUlLER ET AL., DifFERENTIAL RESPONSE IN ILLINOIS: FINAL EVALUATION REPORT 6-10 (2013) [hereinafter FULLER ET AL., FINAL QIC-DR IL REPORT], available at http://cfrc.illinois.edu/pubs/rp_20140205_ DifferentialResponseInIllinoisFinalEvaluationReport.pdf, archived at http://perma.cc/PA8K QHRJ; Lisa MERKel-Holguin et AL., NATIONAL Quality ImProvement Center ON Differential Response in Child Protective Services, Final Report: QIC-DR CrossSite Evaluation 5-23 (2014), available at http://www.ucdenver.edu/academics/ colleges/medicalschool/departments/pediatrics/subs/can/QIC-DR/Documents/Final\%20Cross \%20Site\%20Evaluation\%20Report.pdf, archived at http://perma.cc/H8U5-7FNW; Tamara L. Fuller et al., Differential Response Family Assessments: Listening to What Parents Say About Service Helpfulness, 39 CHILD ABuse \& NEGLECT 7, 7-8 (2015).

3. See Steve Olson \& Clare Stroud, Inst. of Med. \& Nat'l Research Council, Child Maltreatment Research, Policy, And Practice for the NeXt DeCade 84 (2012), available at http://www.nap.edu/catalog.php?record_id=13368, archived at http://perma.cc/ FXC8-EQPR.

4. See generally BARTHOLET, supra note 1 , for a critique of the child welfare system's excessive bias for family preservation at the expense of children's interests.

5. See Kristin Abner \& Rachel A. Gordon, Differential Response: A Family IMPACT ANALYSIS 6 (2012), http://www.familyimpactseminars.org/fia_analyses_drfia.pdf, archived at http://perma.cc/8W6B-MSQB. A major push was provided by the Harvard Executive Sessions of New Paradigms for Child Protection between 1994 and 1997, funded by the Annie E. Casey and Edna McConnell Clark Foundations. Id. at 5. Missouri subsequently established a DR system which became a model for other states, and by late 2010, twenty-one states had implemented DR in at least some part of their systems. JOANNE Ruppel et al., Differential Response in Child Protective Services in New York State: ImPlementation, Initial Outcomes And ImPaCts of Pilot Project 5-6 (2011), available at http://www.ocfs.state.ny.us/main/reports/CPS\%20Differential\%20Response \%20Evaluation\%20Final\%20Report_\%20Jan\%202011.pdf, archived at http://perma.cc/ 33XM-8HL3.

6. Ronald C. Hughes et al., Issues in Differential Response, 23 RES. ON SOC. WoRK PRAC. 493, 494 (2013).

7. Merkel-Holguin ET AL., supra note 2, at 17-18 fig. 2.1; see also IOM/NRC 2014 Report, supra note 2, at 199; Kai Guterman et Al., CAsey Family Programs, The 
government gave DR a boost in 2010 by reauthorizing the Child Abuse and Prevention Treatment Act (CAPTA) ${ }^{8}$ with language requiring states to include "differential response in triage procedures for the appropriate referral of a child not at risk of imminent harm to a community organization or voluntary preventive service."

The wealthy and powerful Casey Family Programs has combined with the American Humane Association, the Institute of Applied Research (IAR), and the Kempe Center for the Prevention and Treatment of Child Abuse and Neglect, to promote DR, provide technical assistance in implementing DR, and design and implement the research used to claim that DR is an evidence-based success story. ${ }^{10}$

Casey Family Programs has played a central role. Its policy team maintains a major presence on Capitol Hill, in state governments, and in major child welfare policy forums around the country. ${ }^{11} \mathrm{Ca}$ sey's financial and human resources provide a unique ability to influence policy. ${ }^{12}$ It has supported DR in a major way since 2003 when it

Differential Response (DR) Implementation Resource Kit: A Resource for JURISDICTIONS CONSIDERING OR PLANNING FOR DR 6 (2014) (stating that DR exists in relatively pure form in twenty-two states, with similar system reforms operational in eight additional states, and another twelve states currently considering or planning DR implementation); OlSON \& STROUD, supra note 3, at 84; Daniel Heimpel, Differential Response Dealt Heavy Blow, The Chronicle of Soc. Change (June 24, 2014), https://chronicleofsocialchange.org/analysis/differential-response-dealt-heavy-blow-2/7289, archived at http://perma.cc/DR7Z-2J77 (noting that DR has spread to as many as thirty states). By 2009, the percentage of screened-in child maltreatment reports referred to DR reached roughly $9 \%$. ABNER \& GORDON, supra note 5, at 16 fig. 1.

8. CAPTA Reauthorization Act of 2010, Pub. L. No. 111-320, 124 Stat. 3459 (codified as amended at 42 U.S.C. $\S 5106 \mathrm{a}(\mathrm{b})(2)(\mathrm{B})(\mathrm{v})(2012)$ ).

9. John D. Fluke et al., Thinking Differentially: A Response to Issues in Differential Response, 23 RES. ON SOC. WORK PRAC. 545, 546 (2013).

10. See, e.g., Merkel-Holguin ET AL., supra note 2, at 5; see also infra Parts IV, IV.B.1 IV.B.4, V.C. The Casey Family Programs DR Implementation Kit referred to supra note 7 is designed to persuade and enable new jurisdictions to adopt DR, providing them a positive slant on the evidence regarding DR along with information as to how other jurisdictions have implemented DR. This Kit documents some of the special funding and technical assistance provided to DR programs by Casey Family Programs, Casey cousin the Marguerite Casey Foundation, IAR, and organizations involved in the QIC-DR, as discussed infra Part IV.B.1, 4 below, including the Kempe Center. See, e.g., GuTERMAN ET AL., supra note 7 , at $57,59,62$.

11. Memorandum from Sean Hughes on Differential Response, Racial Disproportionality, and Fed. Fin. Reform: Casey Family Programs and the Movement to End Foster Care in America, to author and Daniel Heimpel, Founder and Director, Fostering Media Connections 3 (Aug. 28, 2013) (on file with the author). This research memorandum was written for Elizabeth Bartholet and Daniel Heimpel based on research in spring and summer 2013. Together with Daniel Heimpel of Fostering Media Connections and with the aid of several research and investigation fellows, I have been investigating since June 2013 DR policy and research as well as related issues involving the current state of the Racial Disproportionality movement.

12. $I d$. 
sponsored a Breakthrough Series Collaborative on $\mathrm{DR}^{13}$ and "formed a partnership with [California counties] . . . to develop, test, and begin implementing differential response . . .." ${ }^{14}$

One observer sums up:

Perhaps the most important common thread has been the extent to which Casey Family Programs has been the primary proponent and funder of [the DR and related finance reform movement along with other family preservation efforts]. . . . Notably, [these] movements possess at their core a commitment to reducing out-of-home care placements. This supports Casey's 2020 goal of reducing foster care caseloads by half, and helps explain why Casey has invested so heavily .... ${ }^{15}$

This kind of family preservation movement has enormous power to shape the child welfare system. It is designed to change the way CPS systems use their broad discretionary power to decide whether or not to intervene in families to protect children against parental abuse and neglect. It may or may not be translated into formal law requiring CPS systems to implement DR. But regardless, it operates effectively as law, changing the nature of our child protection systems. As such, it constitutes an end run around legislation like the federal Adoption and Safe Families Act of 1997 (ASFA), which was designed to reduce family preservation bias and make child safety and well-being a higher priority. ${ }^{16}$ So, for example, ASFA tells state CPS systems and courts that children must be removed from parents found responsible for certain forms of dangerous child maltreatment, but those ASFA requirements are inapplicable if CPS never intervenes to make such findings.

The DR movement promotes two inter-related ideas. First is to divert the vast majority of cases now on the CPS track to a purely voluntary, "family-friendly" track. ${ }^{17}$ "Family" means parents, because the basic idea is to be friendly to parents accused of maltreating chil-

13. Casey Family Programs, Implementing Differential Response in CALIFornia: Promising PRACTICES AND LESSONs LEARned vi (2007), available at http://www.cfpic.org/pdfs/BSCDifferentialResponseCA.pdf, archived at http://perma.cc/ 7SNT-H777.

14. Id.; see also Heimpel, supra note 7 ("Casey Family Programs . . . has poured money into DR expansion from California to Illinois.”).

15. Memorandum from Sean Hughes, supra note 11, at 65; see also Daniel Heimpel, 'Alternative Response' Is No Solution to Child Abuse [Commentary], BALT. SUN (July 17, 2014), http://articles.baltimoresun.com/2014-07-17/news/bs-ed-alternative-response-2014 0717_1_child-abuse-neglect-child-welfare, archived at http://perma.cc/HF7E-L3X7 (noting Casey Family Programs' lobbying strength and its substantial investments in reducing foster care placements). See generally Part IV for Casey Family Programs' role in DR.

16. Adoption and Safe Families Act of 1997, Pub. L. No. 105-89, 111 Stat. 2115 (1997) (codified as amended at 42 U.S.C. § 671(a)(15)(A) (2000)); see also BARTHOLET, supra note 1 , at 188-89 (discussing the ASFA).

17. See discussion infra Part II.A. 
dren. Under DR parents are to be free from intervention by CPS, intervention which can take the form of monitoring to ensure child safety at home, requirements to cooperate in rehabilitative treatment, removal of children to foster care as needed for their protection, and in the most extreme cases, termination of parental rights and placement of children in adoption. DR advocates say that their friendly approach will serve children better than the CPS system because it will more likely engage parents, and they point out that the CPS system fails to provide most of the families on its caseload with any helpful services. They also argue that when CPS uses its power to remove children to foster care, it often does more harm than good. ${ }^{18}$

The second idea is to finance the DR system with funds diverted from the traditional CPS system. ${ }^{19}$ Those promoting DR are pushing for what they call child welfare finance reform. The major focus is on changing the federal finance structure so as to shift federal funds now going to support foster care to the new DR system. In addition, DR advocates encourage the redirection of state and local funds allocated for CPS general operations to the DR system. ${ }^{20}$ This finance reform idea, again, cuts against the principles animating ASFA. ASFA's goal of getting CPS and courts to put a higher priority on child interests and child protection calls for an increase, not a decrease, in CPS resources.

The history ${ }^{21}$ here is important in understanding the nature of this new movement and the risks it presents to children. DR is a successor to two earlier "reform" movements similarly designed to keep more children at risk of maltreatment at home with their parents: Intensive Family Preservation Services (IFPS) ${ }^{22}$ and Racial Disproportionality. ${ }^{23}$ All three movements have engaged in a similar strategy, impressive in its sophistication. The advocacy groups involved in each movement have promoted the policy reform initiative; promoted the self-serving but fundamentally flawed research designed to give the impression that the new policy was successful; launched campaigns to persuade a broad range of players from policymakers, to academics, to media of its wisdom; and promoted implementation by

\footnotetext{
18. See discussion infra Part II.A.

19. See discussion infra Part II.B.

20. See discussion infra Part II.B.

21. See discussion infra Part I.

22. See generally BARTHOLET, supra note 1, at 114-21 (describing IFPS programs and

23. See Elizabeth Bartholet, The Racial Disproportionality Movement in Child Welfare: False Facts and Dangerous Directions, 51 ARIz. L. REV. 871, 873-74 (2009).
} research). 
child welfare administrations throughout the nation and by state and federal legislatures. ${ }^{24}$

In the past, these reform initiatives have largely collapsed as the research has been found flawed and fraudulent and as the risks to children have become obvious. But memories in the child welfare field seem short.

History is repeating itself with the DR movement. DR advocates make the familiar claim that DR is "evidence based," that it will save money by reducing foster care and thus costs to the state, but magically that it will not put children at any risk. ${ }^{25}$ However, the flaws in the DR research are blatantly obvious, as is discussed in Part IV below. The risks DR poses for children are similarly obvious. Research shows that children on the traditional CPS track are at enormous risk of repeat maltreatment by their parents. If kept at home, most will continue to be abused and neglected. If removed to foster care and then returned home, most will be again abused and neglected. The large majority of the CPS caseload that DR is designed to move to the voluntary track are not minor "dirty house" or "mere poverty" cases, as advocates often contend. CPS legislation is designed to protect poor parents from state intervention based on circumstances beyond the parents' control. The cases in which CPS intervenes generally involve serious drug and/or alcohol abuse, forms of "neglect" that are known to destroy kids' chances for normal development, and situations where serious violence exists but is simply not obvious. ${ }^{26}$

We do need to protect children better. Families on the CPS caseload are not receiving the supportive and rehabilitative services they need. Children are not receiving the protection they need.

But there is no reason to believe that simply removing the power of CPS to monitor these families, to require cooperation with rehabilitative treatment, and to remove children from parents will work better to protect children. Research reveals that while it is hard for parents to free themselves from drug and alcohol addiction, coercive pressure to engage in treatment does sometimes work. ${ }^{27}$ Polite requests to engage in treatment on a purely voluntary basis are not likely to work better or, indeed, as well. ${ }^{28}$

24. See supra notes 22-23; infra Parts I.A, I.B, II, IV, V.C.

25. See Parts IV.B.1.d,IV.B.1.e, IV.B.4.b.

26. For documentation of the claims in this paragraph, see BARTHOLET, supra note 1, at 82-85, 233-35; Elizabeth Bartholet, Creating a Child-Friendly Child Welfare System: Effective Early Intervention to Prevent Maltreatment and Protect Victimized Children, 60 BUFF. L. REV. 1323, 1323-24 (2012); discussion infra Part III.A, III.B.1.a, III.B.1.b.i.

27. See discussion infra Part III.B.1.b.i.

28. See discussion infra Part III.B.1.b.i. 
We need to strengthen the CPS system, provide it with more resources to monitor parents, and provide more parents with more rehabilitative services. We need to do a version of differential treatment but within, and not outside of, the context of the CPS system; so rehabilitative treatment can be required, not just suggested, and so children can be protected in cases in which parents are unable or unwilling to take the necessary steps to become capable of nurturing.

CPS should, of course, be targeting different kinds of family situations with different types of treatment - to a great degree, CPS does that now. For many families, that means keeping the children at home with supportive and rehabilitative services. But CPS will need more resources to do its job better. It keeps many children at home now with few, if any, services provided, ${ }^{29}$ in significant part because it is forced to triage and devote most of its limited resources to the most serious cases.

We also need to strengthen CPS by improving its ability to protect children through removal and through termination of parental rights and adoption, as needed. Nobody wants children to go through unnecessarily the disruption of removal to foster care or termination of parental rights and adoption. But research reveals that foster care operates to protect children against the risk of death and other serious harm at home. ${ }^{30}$ It would work better for children if more often it was followed by timely termination of parental rights and adoption. ${ }^{31}$ Adoption works well for children, generally, but it works best when they have not suffered lengthy periods of maltreatment or foster drift. ${ }^{32}$

DR proponents claim that by removing significant numbers of children from the CPS system, they will free that system to do a better job for the most serious abuse and neglect cases. ${ }^{33}$ But DR is designed not simply to remove children from the CPS system, but also to weaken that system. The goal is not simply to divert children, but also to divert resources from the already resource-starved system to

29. See Patricia L. Kohl, Unsuccessful In-Home Child Welfare Service Plans Following A MALTREATMENT InVESTIGATION: RACIAL AND ETHNiC DifFERENCES 5 (2007), available at http://www.f2f.ca.gov/res/pdf/Unsuccessfulln-Home.pdf, archived at http://perma.cc/5FLG-A5AM (stating that in the overwhelming majority of cases that come to the attention of CPS, the child is kept at home with a biological parent or another caregiver and with many families - even those with substantiated maltreatment-not receiving services).

30. See discussion infra Part III.A.

31. BARTHOLET, supra note 1 , at $97,110$.

32. Id. at 179; Bartholet, supra note 23, at 896-97.

33. Daniel Heimpel \& Elizabeth Bartholet, DCF Shift Puts Children's Safety at Risk, THE HARTFORD COURANT, Jan. 24, 2014, available at http://articles.courant.com/2014-0124/news/hc-op-dheimpel-connecticut-dcf-children-safety-at--20140124_1_dcf-responsechildren, archived at http://perma.cc/LNJ3-UR3G. 
fund the new voluntary track system. It would leave CPS less, not more, able to appropriately handle the most serious cases.

There are reasons why many child welfare leaders keep promoting extreme family preservation movements. Child maltreatment is rooted in poverty and in the conditions associated with poverty, including unemployment, substance abuse, and devastated neighborhoods. ${ }^{34}$ Those committing child maltreatment are themselves victims. Many who have promoted extreme forms of family preservation over the years see CPS intervention-including, in particular, removal to foster care and adoption-as yet another form of victimization. ${ }^{35}$ And they see the kinds of financial support family preservation programs like DR provide as at least some help in alleviating some of the financial needs of poor parents.

But DR cannot be justified as a poverty program. It provides pathetically limited financial stipends to a small and irrationally selected subset of the poor-those who abuse and neglect their children. This will do nothing significant to change poverty conditions in our society.

Worse, DR sacrifices a subset of poor children-those abused and neglected-condemning them to a childhood of suffering that will also limit their life opportunities as adults. If our society honored children as having moral worth equivalent to adults and honored child human rights as being equivalent to adult human rights, we would not tolerate the extreme family preservation policies that regularly reappear. Children would be seen as having a fundamental human right to grow up with nurturing parents, a right of equal importance to the adult right to raise children free from state intervention.

We do need to address the conditions of poverty that create child maltreatment, but we need to address them in a serious way, through radical social change. In the meantime, we need to develop targeted maltreatment prevention programs designed to reach parents before they fall into the dysfunction associated with child maltreatment. And for those children victimized by serious maltreatment, we need a CPS system that is strengthened enough to provide real protection through adequate supportive services, required rehabilitation programs, quality foster care, and adoption for those children whose parents cannot provide nurturing parenting.

34. See Bartholet, supra note 23, at 874-76.

35. Id. at 887 . 


\section{Prior History: Extreme Family Preservation MOVEMENTS SUPPORTED BY ADVOCACY RESEARCH}

I have written previously of the corrupt merger of policy advocacy with research in the movements supporting both IFPS and Racial Disproportionality. ${ }^{36}$ Here I will briefly summarize the highlights. There are other family preservation movements with similar characteristics; but the IFPS and Racial Disproportionality movements best illustrate the troubling dynamics that have characterized child welfare advocacy and related research over the last few decades and that are at issue in the DR movement today.

\section{A. Intensive Family Preservation Services}

IFPS was avidly promoted from the 1970s through the 1990s by the Edna McConnell Clark Foundation and the Annie E. Casey Foundation. ${ }^{37}$ It swept the nation and was adopted by many states' child welfare systems. The basic idea was to define children who are identified as abused and neglected as being "at risk of removal" to foster care, with the goal of keeping as many as possible at home. The means was to provide social worker support services on an intensive basis for roughly six weeks based on the absurd notion that child maltreatment was typically a short-term crisis.

The research evaluating IFPS focused not on how well or badly the program served child interests, but instead on whether IFPS succeeded in its goal of keeping children at home, thus saving the state money through the reduction of foster care costs. It took years for child welfare experts to focus on the flaw at the heart of the research, namely that it paid no attention to child interests. Eventually those analyzing the research also noted that IFPS failed even to succeed in its family preservation goal. In the end, the program was seriously discredited and largely abandoned. ${ }^{38}$

One article provides a telling critique of the earlier IFPS research, noting methodological problems, failure to reduce removal, and failure to focus on child well-being. It concludes with a call for more appropriate research in the future:

36. See Bartholet, supra note 26, at 1334-35, 1340-42; Elizabeth Bartholet, Creating a Child-Friendly Child Welfare System: The Use and Misuse of Research, 13 WHITTIER J. CHILD \& FAM. ADVOC. 8-15 (2014) [hereinafter Bartholet, The Use and Misuse of Research]; see generally Bartholet, supra note 23 (focusing solely on Racial Disproportionality).

37. See Bartholet, supra note 26, at 1332; see also BARTHOLET, supra note 1 , at 141 , 154; Richard J. Gelles, The Book of David: How Preserving Families Can Cost CHILDREN's Lives 122-35, 139-40 (1996).

38. GELles, supra note 37, at 139-40; IRA M. SCHWARTZ \& GIDEON Fishman, Kids RAISED BY THE GOVERNMENT 44-46 (Simon Hakim ed., 1999). 
$[\mathrm{M}]$ ore attention should be directed toward determining whether the child's overall functioning has improved because of the services received. Has abuse or neglect reoccurred? Have the child's growth and development been optimized? Has the child's cognitive and social development shown changes for the better? These and other outcomes will need to be addressed to obtain a clearer understanding of the benefits and limitations of family preservation. . . . Alternatives to family preservation, such as permanency planning (adoption) and foster care, also must be reexamined . . . Applying family preservation to every family, as a matter of policy, may actually be placing children at risk. ${ }^{39}$

Richard Gelles documents in Book of David the degree to which this private foundation advocacy was responsible for the IFPS movement and for its success for many years in changing the nation's child welfare system:

[T] he expansion of the concept of family preservation and the growing support for the programs[] . . . could not have been achieved without the support, financial and otherwise, of two large and influential foundations. The Edna McConnell Clark Foundation .... and the Annie E. Casey Foundation[] . . played crucial roles in the selling, or overselling, of family preservation.

Both foundations marketed family preservation with a nearreligious zeal and substantial financial support. They funded startup and demonstration programs and then promoted them.

[They] became the official repositories of expertise and data on family preservation. State, local, and federal agencies and officials ... relied on the two foundations for their evaluation data.

$\cdots$

When the believers are foundations who can invest millions of dollars each year in touting the programs and when the critics are academics who merely publish their research results in scholarly journals, the outcome is entirely predictable. State and local agency heads, legislators and legislative aides, governors and presidential administrations were told about the unqualified successes of family preservation and the tremendous cost savings. The skeptics and critics were either unknown or cast as merely academic gadflies. ${ }^{40}$

39. Amy M. Heneghan et al., Evaluating Intensive Family Preservation Programs: A Methodological Review, 97 PEDIATRICS 535, 541 (1996); see also Viola VaughanEden \& Frank E. Vandervort, Invited Commentary on "Issues in Differential Response," 23 RES. ON SOC. WORK PRAC. 550, 551-52 (2013) (discussing the relevance of the IFPS history to the DR movement).

40. GELLES, supra note 37, at 133-35. 


\section{B. Racial Disproportionality}

Racial Disproportionality was avidly promoted by various Casey Foundations, ${ }^{41}$ together with a broad consortium of establishment child welfare organizations, in the early part of this century. ${ }^{42}$ What came to be known as the Casey Alliance led the movement, working to get every state to adopt policies designed to reduce the number of black children removed to foster care with the goal of achieving a match between their percentage of the foster care population and their percentage of the general population. The Alliance also began work to get the federal government to condition its funding of state child welfare systems on their ability to achieve this "racial equity" goal.

The basic idea was that the removal of black children in numbers disproportionate to their population percentage was caused by current racial bias in the child welfare system. This racial bias claim relied almost entirely on research known as the National Incidence Study (NIS), which stated in its 1996 NIS-3 Report that actual rates of maltreatment by black and white parents were the same, and accordingly, that bias must explain the different rates of removal to foster care.

The Casey Alliance used its wealth both to promote policy advocacy on these issues and to fund related research. For example, it approached states throughout the country saying: we will help study your racial disproportionality problem, write the report stating the nature of your problem, and then help solve your problem with appropriate new policies. These state reports' claims regarding bias almost all come back to the NIS research.

The Casey Alliance successfully sold the idea that racial bias in the CPS system was responsible for the number of black children in foster care to policymakers, academics, and the media. But the claim on which the racial bias theory was primarily based, that black maltreatment rates were the same as white maltreatment rates, was false. The NIS-3 Report's own data, hidden in a later-published appendix, showed that actual black maltreatment rates were higher than white maltreatment rates, and that the difference in rates approximated the difference in official maltreatment reports and related removal rates. There was a lot of other evidence available to the Casey Alliance demonstrating that the NIS-3 claims regarding comparative rates and system bias were likely wrong. A major conference on Racial Dis-

41. The Casey organizations were the Anne E. Casey Foundation, Casey Family Services, Casey Family Programs, The Jim Casey Youth Opportunities Initiative, and the Marguerite Casey Foundation. Bartholet, supra note 23, at 880.

42. See, e.g., Bartholet, supra note 26, at 1340-42; Bartholet, The Use and Misuse of Research, supra note 36, at 9-15. For more specifics on the Racial Disproportionality movement summarized here, see generally Bartholet, supra note 23. 
proportionality at Harvard Law School (HLS) in 2011 presented research by many eminent social scientists demonstrating that there was no basis for the NIS-3 claims in the authors' own data, and that the claims were inconsistent with persuasive, independent research.

By the time of this HLS conference, the NIS-4 Report had been released, and the authors had conceded that then, with a larger sample, they found a statistically significant difference between actual black and white maltreatment rates, without conceding any error in their previous claims regarding comparative rates and racial bias.

The conference organizers co-authored a paper, published as an Issue Brief by the conference co-sponsor, Chapin Hall at the University of Chicago, a highly respected research institute. The paper stated that the evidence presented at the conference helped demonstrate that higher rates of black family contact with the child welfare system reflected higher rates of actual maltreatment. It concluded:

We believe that the evidence presented at this conference signals that it is time for reconsideration of certain past assumptions and conclusions. It indicates that generally there is a significant black/white maltreatment gap, one that roughly parallels the gap in official maltreatment reports. This evidence contradicts the belief that black children are included at high rates in the child welfare system because of racial bias. ${ }^{43}$

I concluded in a related article:

At a minimum, the [Racial Disproportionality] claim regarding discrimination was irresponsible, and grounded on bad social science that flew in the face of a large body of contrary evidence. It helped make the case for keeping more black children with parents accused of maltreatment, despite the fact that if black children were subject to disproportionately high rates of maltreatment, they should for their own protection be removed at similarly high rates. ${ }^{44}$

The Racial Disproportionality movement has been significantly disrupted. A chapter in the recent publication, Handbook of Child Maltreatment, concludes that the HLS conference and my related work have resulted in a change in the dialogue on this issue, such that racial disproportionality can no longer be equated with racial bias, and proportionate representation can no longer considered be an appropriate goal. ${ }^{45}$ However the movement has not been entirely

43. See Elizabeth Bartholet et al., Race and Child Welfare, CHAPIN HALL 4 (June 2011), http://www.chapinhall.org/sites/default/files/publications/06_27_11_Issue\%20Brief_ F.pdf, archived at http://perma.cc/7GAL-LSJN.

44. Bartholet, supra note 26, at 1343 .

45. Alan J. Dettlaff, The Evolving Understanding of Disproportionality and Disparities in Child Welfare, 2 CHILD MALTREATMENT HANDBOOK149-68 (Jill E. Korbin \& Richard 
derailed. Movement proponents continue to promote its claims and goals. And many of those supporting the movement have simply shifted energy and resources toward supporting DR. ${ }^{46}$

In DR we see the historical pattern playing out once more. We again have powerful private organizations mounting a sophisticated campaign to promote an extreme family preservation policy. We again have self-serving research deployed as a central part of the strategy, research that ignores important child interests in safety and well-being. We again have policymakers blindly accepting the research claims and embracing this new silver-bullet fix that promises to improve the child welfare system while saving states money.

We also are beginning to see the emergence of a serious challenge to the DR movement. Some of this is based on a debate that has erupted in the social science community, with the validity of the advocacy research that the DR movement has propagated now being questioned by independent social scientists. ${ }^{47}$

\section{NATURE OF THE DIFFERENTIAL RESPONSE MOVEMENT}

\section{A. Program Characteristics}

While DR programs vary in details, most share certain core essentials, and DR proponents advocate for these essentials. ${ }^{48}$

\section{The Diversion Goal}

$\mathrm{DR}$ is designed to divert a large percentage of the cases that are traditionally under CPS jurisdiction to the new, voluntary AR track. Advocates often talk of diverting something in the range of $70 \%$ of CPS cases. ${ }^{49}$ Current programs vary significantly in the percentage

\begin{tabular}{l}
\hline D. Kingman eds., 2014), available at http://link.springer.com/ \\
chapter/10.1007/978-94-007-7208-3_8. \\
46. Memorandum from Sean Hughes, supra note 11, at 16-22. Many argue that DR \\
will help to reduce disproportionality and many keep track of race statistics as part of their
\end{tabular} will help to reduce
DR analyses. Id.

47. See discussion infra Part IV.B.3.

48. See, e.g., RUPPEL ET AL., supra note 5, at 9 (listing in a chart core essentials and differences between Family Assessment Response and Traditional Investigative Response); see also MERKEL-HOLGUIN ET AL., supra note 2, at 5-13 (contrasting AR and TR).

49. Elizabeth Bartholet \& Daniel Heimpel, Through the Cracks, BosTon GLOBE, Dec. 24, 2013, available at http://www.bostonglobe.com/opinion/2013/12/24/saving-childrenfrom-our-child-welfare-system/euxaDvobzhfhY7zpm1CYmO/story.html, archived at http://perma.cc/AXK9-WTRW; Daniel Heimpel, Are Child Protection Quotas Endangering Minnesota Children?, THE Chronicle OF Social ChANGe, Sep. 22, 2014, available at https://chronicleofsocialchange.org/news/are-child-protection-quotas-endangering-minnesotachildren/8162, archived at https://perma.cc/5YPW-QWN6 (quoting Eric Fenner, the managing director at Casey Family Programs, who stated that they had "goals of 70 percent"); see also Daniel Heimpel, Does Race Influence Child Protection Efforts in Minnesota?, 
diverted, from $8 \%$ to over $70 \%$, with the percentage in any given program generally increasing over time. ${ }^{50}$

The cases to be diverted are characterized as low-risk, or low- to medium- risk, though as discussed below there are serious questions as to whether these characterizations actually fit the cases being diverted. ${ }^{51}$

Diversion at the front end reduces the likelihood that children will ever be removed from their parents. If children are not under CPS jurisdiction in the first place, then CPS is less likely to accumulate the evidence supporting a removal to foster care or termination of parental rights and adoption. This fits with the longstanding Casey Family Programs goal of reducing foster care by $50 \%$ by $2020 .{ }^{52} \mathrm{Ca}$ sey makes clear that it links DR with this reduction goal. ${ }^{53}$ That goal also fueled the Racial Disproportionality movement, with Casey thinking it could achieve half of its foster care reduction goal just by eliminating disproportionality. ${ }^{54}$

\section{Voluntary, Not Coercive}

The AR track is entirely voluntary for parents. At the outset, they can accept or reject the offer to participate in the AR program, with no consequence for rejecting it. They can also start down the AR track but can get off of it at any point they choose, again with no con-

STARTRIBUNE, Oct. 17, 2014, available at http://www.startribune.com/does-race-influencechild-protection-efforts-in-minnesota/279629742/, archived at http://perma.cc/W9Y8-J45N.

50. See Theodore P. Cross et al., What Will Happen to this Child if I Report? Outcomes of Reporting Child Maltreatment, Presentation at the APSAC Conference 20 (June 2014) (on file with author); see also Alicia Kyte et al., Evaluating Where We're at with Differential Response, 37 CHILD ABUSE \& NEGLECT 125, 129 (2013) (stating that approximately $60 \%$ to $80 \%$ of cases are diverted to a DR track in many states); C. Nicole Lawrence et al., Multiple Response System: Evaluation of Policy Change in North Carolina's Child Welfare System, 33 CHILD. \& YouTH SERVICES REV. 2355, 2364 (2011) (stating that 70\% to $80 \%$ of cases in the North Carolina system were diverted to DR programs and $42 \%$ to $71 \%$ of cases were diverted to DR programs in other states).

51. See discussion infra Part III.B.1.a.iii (discussing the evidence as to the actual risk level of the cases being diverted).

52. Casey family Programs, Moving Toward Hope: Paths to Keep Children SAFe, Make FAmilies Strong AND Build Supportive Communities 5 (2013) ("When we launched our 2020 Strategy for America's Children in 2006, some questioned our goal to safely reduce by 50 percent the number of children in foster care in the U.S. by the year 2020." (statement of Shelia Evans-Tranumn, Chair, Board of Trustees)); CASEY FAMILY Programs, 2008 CASEY FAMily PROGRAms ANNUAL RePort 23 (2008) [hereinafter 2008 CASEY FAMILY PROGRAMS ANNUAL REPORT] (on file with author).

53. 2008 CASey Family Programs AnNual RePort, supra note 52, at 23 ("Casey Family Programs has championed differential response for several years as an effective practice that safely reduces the number of children entering foster care. Our paramount goal is to safely reduce the number of children in foster care by 50 percent by the year 2020.”).

54. Id. at 33 . 
sequence. ${ }^{55}$ Thus, parents who are thought to be responsible for child maltreatment and who are assigned to the AR track can simply walk away from any rehabilitation services or requirements and any monitoring or surveillance.

Evidence that parents continue to mistreat their children can generate a decision to move the family that is initially assigned to AR to the traditional or TR track, ${ }^{56}$ but the system is not designed to place much emphasis on looking for such evidence. AR track social workers might become aware of maltreatment, in which case they would be obliged as mandated reporters to report it to CPS. But the overall goal of the $\mathrm{AR}$ system is to embrace diversion and parent-friendly policies, and it appears that generally, little emphasis is placed on identifying maltreatment.

Also, parents who refuse participation from the outset will not be seeing social workers, so there will not be the kind of evidence of maltreatment that would surface when parents meet regularly with social workers as required in the traditional CPS system.

In fact, only a tiny percentage of AR families are actually switched from the AR to the TR track based on social workers' conclusions that children were wrongfully assigned to AR or were otherwise in danger. The state reports that reveal evidence of switch rates show rates ranging from $2 \%$ (Virginia), ${ }^{57}$ to $3 \%$ (Colorado), ${ }^{58}$ to $3.5 \%$ (Illinois); ${ }^{59}$ to $4 \%$ (Ohio) ${ }^{60}$; and for three New York counties, from $0.3 \%$, to $1.2 \%$, to $5.6 \%{ }^{61}$ These figures are troubling given the

55. Kathryn A. Piper, Differential Response in Child Protection Services: A Comparison of Implementation and Child Safety Outcomes in Eight States 39 (June 17, 2014) (unpublished dissertation, Brandeis University) (on file with author).

56. In the Colorado system, safety concerns may trigger a referral from AR to TR. See Marc Winokur et al., Social Work Research Ctr. at Colo. State Univ., Program Evaluation of the Colorado Consortium on Differential Response: FINAL REPORT 25-26 (2014), available at http://www.ucdenver.edu/academics/ colleges/medicalschool/departments/pediatrics/subs/can/QIC-DR/Documents/Program\% 20Evaluation\%20of\%20the\%20Colorado\%20Consortium\%20on\%20Differential\%20Respo nse\%20-\%20Final\%20Report.pdf, archived at http://perma.cc/37ZP-Y4BL.

57. Commonwealth of Virginia, DeP'T of Soc. Servs., Evaluation of the DIFFERENTIAL RESPONSE SYSTEM 12 (2008), available at https://www.dss.virginia.gov/ files/about/reports/children/cps/all_other/2008/differentialresponsesystem_evaluation_an nualreport_2008_12-08.pdf, archived at https://perma.cc/N6MN-SUH8.

58. WINOKUR ET AL., supra note 56, at 34 .

59. FULleR ET AL., FINAL QIC-DR IL REPORT, supra note 2, at 30 (noting that another $9.8 \%$ were switched based on new screened-in maltreatment reports).

60. L. Anthony Loman \& Gary L. Siegel, Effects of Approach and Services Under Differential Response on Long Term Child Safety and Welfare, 39 CHILD ABuse \& NEGLECT 86, 91 (2015), available at http://www.sciencedirect.com/science/article/pii/S0145 213414002099, archived at http://perma.cc/7EZQ-N7U8 (percentage calculated based on Ohio figures given).

61. RUPPEL ET AL., supra note 5, at 38. 
evidence that a huge percentage of children in AR families are subjected to ongoing maltreatment. ${ }^{62}$

\section{No Fact-Finding Investigation and No Maltreatment Findings}

In a DR system, there is generally no traditional CPS fact-finding investigation at the outset to determine whether the alleged maltreatment actually occurred and, if so, to assess the related family dynamics in connection with deciding the track on which cases belong. Instead, a "safety assessment" determines the track, often based simply on the limited information gathered in the initial hotline call reporting the incident to CPS, together with certain eligibility criteria. ${ }^{63}$ While some DR systems depart from the movement ideal and use an investigation to make the initial tracking decision, most do not. ${ }^{64}$ The most influential researchers promoting DR's success state: "A primary assumption underlying DR is that the adversarial approach of traditional investigations seeking to validate or invalidate allegations of child maltreatment is unnecessary for all but the most extreme and criminal reports of child abuse and neglect ...." ${ }_{65}$ This assumption governs both the initial approach to the tracking decision and subsequent dealings with the family.

For the first $\mathrm{AR}$ home visit, an appointment is made, as compared to the unannounced first visit in the traditional CPS system. In AR there is no separate interview of the child at risk or other witnesses, as compared to the traditional CPS practice of interviewing alleged victims and other witnesses out of the presence of the alleged perpetrator. Separate interviews are what one would do to find out what happened and whether, for example, a burn on a child is the result of an accident or deliberate torture. But the point in $\mathrm{AR}$ is to be parent friendly, and investigations focused on what parents might have wrongfully done to a child are not thought of as friendly. Accordingly, there is a deliberate effort to avoid focusing on the alleged maltreatment and to avoid identifying the perpetrator. ${ }^{66}$ Instead, the focus is

62. See discussion infra Part III.B.1.a.iii.

63. Hughes et al., supra note 6, at 500 ("[S]creeners in DR programs typically make recommendations for case acceptance, establish the priority for agency response, and recommend a track assignment based on information collected in a referral telephone interviewinformation that is typically limited in scope and depth and potentially in accuracy.").

64. GUTERMAN ET AL., supra note 7, at 16 (showing that a majority of surveyed jurisdictions make the track assignment decision during the central intake/hotline call); RUPPEL ET AL., supra note 5, at 45-46; see also Cross et al., supra note 50, at 4, 6.

65. Loman \& Siegel, supra note 61 , at 87.

66. See, e.g., Hughes et al., supra note 6, at 501 ("A defining characteristic of the alternative DR track is that caseworkers neither substantiate allegations of child maltreatment, nor do they confirm the perpetrator. . . . [Many claim] it unnecessary (and inherently disrespectful) to push families to talk about an alleged maltreatment incident or to determine who was responsible for its occurrence."); id. at 501-02 (inquiring about mal- 
supposed to be on the family's needs and how services might best meet those needs to reduce the risk to children.

For related reasons, there is no finding of maltreatment and no report of perpetrators to a central registry, by contrast to the traditional CPS system. ${ }^{67}$

\section{Financial Support Emphasized over Rehabilitative Services}

Many DR programs provide special funding for their AR tracks, giving AR social workers additional and more flexible funds to provide financial support for parents, as compared to traditional CPS workers. ${ }^{68}$ Accordingly, AR track programs often provide more generous financial support services than their corresponding CPS programs. Special selection and training for AR workers orients them to be more supportive of parents and less critical, as compared to traditional CPS workers.

AR programs generally favor financial support over rehabilitative services, as compared to corresponding CPS programs. So, for example, AR services often consist primarily of financial subsidies for rent payments, the purchase of household appliances, and the like, while CPS programs are more likely to emphasize rehabilitation services designed to enable parental fitness, such as drug and alcohol rehabilitation services and anger management counseling. ${ }^{69}$

\section{B. Related Finance "Reform"}

DR advocates have invested a lot in efforts to change the federal system for funding state child welfare systems. The federal government funds roughly half of all state child welfare budgets, so federal financial policy is all-powerful in determining state child welfare policy. ${ }^{70}$ States simply cannot afford not to do what the federal government says they must do as a condition of receiving federal funds.

treatment dynamics, determining who was responsible, identifying child victim, not considered routine part of information gathering, and often actively discouraged).

67. Brett Brown et al., Differential Response: Early ImPlementation and Fidelity, Cross Site REPort OF NATIONAL QUALITY IMPROVEMENT CENTER ON Differential Response IN Child Protective Services 7 (2012), available at http://www.ucdenver.edu/academics/colleges/medicalschool/departments/pediatrics/subs/can/ DR/qicdr/General\%20Resources/General\%20Resources/docs/cross-site-report-may-2012.pdf, archived at http://perma.cc/58CC-ZE89; Loman \& Siegel, supra note 61, at 87.

68. See MERKEL-Holguin ET AL., supra note 2, at 5, 10, 32, 83.

69. See discussion infra Parts IV.B.1.c, IV.B.4.b.

70. See generally American Humane Association, Federal Funding for Child WELFARE SERVICES, available at http://www.americanhumane.org/assets/pdfs/children/ federal-funding-for-child.pdf, archived at http://perma.cc/Y549-2HJB; EMILIE STOLTZFUs, Child Welfare: An Overview of Federal Programs and Their CurRent Funding (2015), available at http://greenbook.waysandmeans.house.gov/sites/greenbook. waysandmeans.house.gov/files/R43458_gb_1.pdf, archived at http://perma.cc/5WLQ-FCCK; 
Casey Family Programs has been a major presence, lobbying in the Administration and Congress in recent years for what it calls federal finance reform. ${ }^{71}$ It has worked with the American Humane Association (AHA) to get other important organizations to join this effort, including the Child Welfare League of America, the National Association of Public Child Welfare Administrators, the Center for Law and Social Policy, and the Children's Defense Fund. ${ }^{72}$ This has become an increasingly important strategy for expanding DR nationwide and, if successful, would free up vast new resources for DR programs while simultaneously diverting those resources away from the traditional CPS system and, in particular, foster care..$^{73}$

The first step in the program is to enable and encourage states to shift on an experimental and short-term basis some of their federal foster care funding to a new DR system. ${ }^{74}$ The second step will be a push to make this shift in funds long term and mandatory. ${ }^{75}$ This step would require change in the underlying federal child welfare financing system. ${ }^{76}$

Significant progress has already been made on the first step. Congress passed the Child and Family Services Improvement and Innovation Act in $2011,{ }^{77}$ allowing states to conduct five-year demonstration projects with funds saved from reducing foster care. Many states have been using these "Title IV-E waivers" to fund DR programs. ${ }^{78}$

Robert Longley, Federal Funding for Child Welfare: Some States Struggle to Meet Needs, GAO Finds, ABOUT NEWS, available at http://usgovinfo.about.com/od/ federalbenefitprograms/a/Federal-Funding-For-Child-Welfare.htm, archived at http://perma.cc/BH6A-5MFK (stating that federal funding varies by state from $25-80 \%$ ).

71. Casey and its allies are promoting their finance reform ideas through, for example, testimony at congressional hearings, participation in House and Senate foster care caucuses, financing publications issued by partner organizations, and their own marketing materials. Memorandum from Sean Hughes, supra note 11 at 4-5, 26-28; see generally, e.g., The Antwone Fisher Story as a Case Study for Child Welfare: Hearing Before the S. Comm. on Fin., 113th Cong. 8-10 (2013) (statement of Eric Fenner, Managing Director of Casey Family Programs); Preventing Child Abuse and Improving Responses to Families in Crisis: Hearing Before the Subcomm. on Healthy Families and Cmtys. of the H. Comm. on Educ. and Labor, 111th Cong. 16-18 (2009) (statement of Caren Kaplan, Director of Child Protection Reform, AHA).

72. Memorandum from Sean Hughes, supra note 11, at 26-28.

73. Id. at $4,23-24$.

74. Id. at $25-26$.

75. Id. at 26 .

76. Id. at 6, 38-58, 60-64 (detailing Casey's monumental finance reform campaign of recent years).

77. Child and Family Services Improvement and Innovation Act, Pub. L. No. 112-34, $\S 201,125$ Stat. 369, 382 (2011). The Act requires states to certify that they are using DR for children found not to be at risk of imminent harm. CAPTA Reauthorization Act of 2010, Pub. L. No. 111-320, § 115, 124 Stat. 3459, 3467-74; see MERKEL-Holguin ET AL., supra note 2 , at 17 . 
Casey believes that these waiver programs will create momentum for more structural changes to the federal child welfare financing system.

Meanwhile, Casey has embarked on a major push to enlist advocates and policymakers in support of the second step. This multifaceted effort has included developing and submitting a finance reform proposal to a key Congressional committee, ${ }^{79}$ and funding coalitions and forums dedicated to pursuing finance reform (including the Partnership to Protect Children and Strengthen Families ${ }^{80}$ and, more recently, a Brookings Institute-led series of meetings with congressional and Administration staff). ${ }^{81}$ The Casey policy team also routinely presents at child welfare gatherings around the country about the need for finance reform. ${ }^{82}$

78. Child and Family Services Improvement and Innovation Act, §§ 101-03; see generally Memorandum from Sean Hughes, supra note 11, at 25. The 2011 Act permits a waiver of the normal requirement of Title I-E of the Social Security Act that funds saved by reducing foster care must be returned to the federal government. See CASEY FAMILY PROGRAMS, DR RESOURCE KIT, supra note 7, at 6; see generally JAMES BELL ASSOCIATES, Inc., Profiles of the Title IV-E Child Welfare Waiver Demonstration Projects (2013), available at http://www.acf.hhs.gov/sites/default/files/cb/waiver_profiles_vol2.pdf, archived at http://perma.cc/GN9D-9TJ5 (describing, on a state by state basis, child welfare demonstration projects).

79. See generally CASEy FAMily Programs, Ensuring SAFE, Nurturing AND

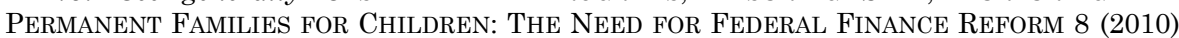
(discussing Casey's involvement in making a push for child welfare reform), available at http://www.casey.org/media/WhitePaper-NeedForFinanceReform.pdf, archived at http://perma.cc/9TRP-TQJ5. The Subcommittee on Income Security and Family Support is now known as the Subcommittee on Human Resources. See Press Release, U.S. House of Representatives Committee on Ways and Means, Chairman Camp Announces Republican Membership on Ways \& Means Subcommittees for 112th Congress (Jan. 6, 2011), available at http://waysandmeans.house.gov/news/documentsingle.aspx?DocumentID=219142 (stating that the Subcommittee on Human Resources was known as the Subcommittee on Income Security and Family Support during the 110th and 111th Congresses).

80. See Memorandum from Sean Hughes, supra note 11, at 45-53.

81. See id. at 53-58.

82. Recently, Casey Staff prepared and helped guide the California Child Welfare Council through a series of proposals that would expand the array of services eligible for federal reimbursement to include those, like DR, that "meet the needs of a child and their family in a family-based setting." CAL. Child Welfare Council, Federal Child Welfare FinANCE REFORM: THE CALIFORNIA FRAMEWORK 2, available at //www.chhs.ca.gov/CWCDOC/3_CA\%20Framework\%20for\%20Finance\%20Reform.pdf (last visited July 26, 2014), archived at http://perma.cc/4WFB-2772; see generally CAL. CHILD Welfare Council, Federal Child Welfare Finance Reform: A Call to action to SUPPORT CALIFORNIA FAMILIES (2013), available at http://www.chhs.ca.gov/CWCDOC/ 4_CalltoAction_Finance\%20Reform.pdf, archived at http://perma.cc/7R4Q-QHWU; CAL. Child Welfare Council, Federal Child Welfare Finance Reform: A Toolkit for CALIFORNIA (2014), available at http://www.chhs.ca.gov/CWCDOC/1_Finance\%20Reform \%20Toolkit\%20Overview.pdf, archived at http://perma.cc/DN7R-GHK6; CAL. CHILD Welfare Council, Federal Child Welfare FinANCE REForm: FACT SheET, available at http://www.chhs.ca.gov/CWCDOC/2_\%20Fact\%20Sheet\%20on\%20Finance\%20Reform.pdf (last visited July 26, 2014), archived at http://perma.cc/N9J7-TYTA; CAL. CHILD WELFARE Council, Federal Child Welfare Finance Reform: The California Framework, available at http://www.chhs.ca.gov/CWCDOC/3_CA\%20Framework\%20for\%20Finance 
Simultaneously, states are being encouraged to shift some of their general CPS support funds from traditional CPS activities to help fund new DR programs-the logic being that as significant numbers of cases are diverted from CPS to DR, expenses for such traditional CPS activities as investigation and monitoring should go down. ${ }^{83}$

The DR movement strategy has been to use the latest stage of selfserving research - conducted as part of the QIC-DR project discussed below ${ }^{84}$ - to demonstrate to the federal Administration and Congress that DR is an evidence-based success story warranting a major shift of federal funds toward DR. But that latest stage of research did not come out as positively as DR proponents had hoped. This, together with the debate in the research community that has erupted and other obvious problems with DR, all discussed below, should encourage those in charge of federal finance policy to consider the pros and cons of DR before radically changing our child welfare financing system in ways that threaten children.

\section{Risks to CHILDREN Posed By DifFERENTIAL RESPONSE}

\section{A. Risks to Children in the Current System}

Many think that CPS fails children by not providing enough in the way of monitoring, rehabilitative services, removal to foster care, and termination of parental rights so they can move on to nurturing, adoptive homes. I tried to document this case, showing that the system is currently guilty of under-intervention, rather than overintervention, in my 1999 book, Nobody's Children. ${ }^{85}$ Part of the problem has to do with unduly limited resources, and another part with undue deference to family preservation and parental rights by both CPS and the courts. ${ }^{86}$

DR advocates claim that their program is justified, in part, because CPS fails to provide services to so many of the cases in its jurisdiction. ${ }^{87}$ But an obvious solution to this problem would be to pro-

\%20Reform.pdf, archived at http://perma.cc/4WFB-2772 (lasted visited July 26, 2014) (documents provided at March 12, 2014 meeting of the California Child Welfare Council).

83. E-mail from Ronald Hughes, Executive Director, North American Resource Center for Child Welfare and the Institute for Human Services (HIS/NARCCW), to author (July 11, 2014, 3:32 PM) (on file with author); e-mail from Sean Hughes, Managing Partner, Social Change Partners, LLC, San Francisco, CA., to author (July 11, 2014) (on file with author).

84. See discussion infra Part IV.B.4.

85. See BARTHOLET, supra note 1, at 98-110.

86. $I d$.

87. Merkel-Holguin ET AL., supra note 2, at 8; Cynthia Godsoe, Just Intervention: Differential Response in Child Protection, 21 BROOK. J. OF L. AND POLICY 73, 75-76 (2012), available at http://practicum.brooklaw.edu/sites/default/files/print/pdfs/journals/journallaw-and-policy/volume-21/issue-1/jlp_v21i_2.pdf, archived at http://perma.cc/63P7-GE87; 
vide CPS with more resources so that it could provide more extensive supportive and rehabilitative services.

There are many different indications of the fact that children are at undue risk for abuse and neglect in the current system. First, official reports indicate that one in eight children will be found by CPS to have been maltreated. ${ }^{88}$ Also, official maltreatment reports provide a serious underestimate of the actual maltreatment suffered. For example, retrospective self-reports reveal that $40 \%$ of children will be maltreated during childhood. ${ }^{89}$ Moreover, while official reports are down recently, hospital data show children at increasing risk of suffering and dying from severe maltreatment. ${ }^{90}$

Second, experts on child maltreatment know that most children on CPS caseloads are at serious risk of the kind of abuse and/or neglect that jeopardizes the ability to grow up healthy and emotionally capable of living a fulfilling life. "[T] he vast majority of families who come to the attention of CPS are quite dysfunctional. Many are overtly pathological and either unable or unwilling to make the changes necessary to provide for their children's physical and emotional safety and/or to provide a minimal level of responsible care . . ." 91 The great majority of CPS children-some $70 \%$ to $90 \%$ are living with parents addicted to drugs and/or alcohol. ${ }^{92}$ By definition, these should be considered cases in which children are at serious risk. ${ }^{93}$

Third, newspaper stories regularly chronicle deaths of children at the hands of their parents, despite the fact that CPS workers are supposed to be monitoring their welfare. ${ }^{94}$ These situations often in-

Patricia Schene, The Emergence of Differential Response, 20 PROTECTING CHILDREN 4, 4-5 (2005), available at http://www.americanhumane.org/assets/pdfs/children/differentialresponse/pc-20-2-3pdf.pdf, archived at http://perma.cc/45Q8-TJ5K.

88. Christopher Wildeman et al., The Prevalence of Confirmed Maltreatment Among US Children, 2004 to 2011, 168 JAMA PEDIATRICS 706, 706 (2014).

89. Id. at 707,710 .

90. While child welfare substantiated maltreatment rates have gone down in recent years, the maltreatment-related severe injury rates recorded in hospital records rose some $5 \%$ from 1997 to 2009. John M. Leventhal \& Julie R. Gaither, Incidence of Serious Injuries Due to Physical Abuse in the United States: 1997 to 2009, 130 PEDIATRICS 847, 850 (2012), available at http://pediatrics.aappublications.org/content/130/5/e847.full.pdf+html, archived at http://perma.cc/MUR2-UDLD.

91. Vaughan-Eden \& Vandervort, supra note 39, at 551.

92. BARThOLET, supra note 1, at 68; see also id. at 67-81, 207-32; John P. Seasock, Identifying Abuse and Neglect in Children Whose Families are Affected by Chemical Dependence, APSAC, http://www.apsac.org/assets/documents/2014_Colloquium/2014_Handouts/ 81\%20workshop.pdf (last visited Feb. 5, 2015), archived at http://perma.cc/8E9H-ZT72 (stating that substance abuse exists in $40 \%$ to $80 \%$ of families where children are abused).

93. See sources cited supra note 92 .

94. See, e.g., Yvonne Abraham, Jeremiah Oliver Was a Little Boy Lost, Bos. GLoBe, Dec. 19, 2013, at B1; Michael Levenson et al., State Family Agency Fires Two in Case of Boy Feared Dead, Bos. Globe, Dec. 17, 2013, at A1; Michael Levenson, State Promoted 
volve cases previously categorized as neglect rather than abuse-cases of the kind that DR advocates argue can be assumed to be minor. ${ }^{95}$ Such stories regularly describe the dangers of extreme family preservation bias ${ }^{96}$ and bemoan CPS failure to intervene more actively in the form of both protective monitoring and removal to foster care. ${ }^{97}$

Fourth, official reports on child welfare problems, often triggered by child deaths, regularly fault CPS for providing inadequate supervision and protection for children and fault legislators as well for the limited funding they provide for CPS. ${ }^{98}$ These reports regularly call for more funding for CPS so that it can reduce worker caseloads and provide better surveillance for children kept at home, more rehabilitative services, and more aggressive intervention. ${ }^{99}$

Social Worker Before Firing Her, Bos. GLoBe, Dec. 31, 2013, at A1; Jenifer McKim, Savage Toll of Abuse for Children in DCF Care, Bos. GLOBE, Feb. 2, 2014, at A1, available at http://www.bostonglobe.com/metro/2014/02/02/massachusetts-children-under-state-protection -die-from-abuse-with-alarming-frequency/2TcwcpIbWnrANkKKQs1CVP/story.html, archived at http://perma.cc/CSK4-5F4W; Carol Marbin Miller \& Audra D.S. Burch, Preserving Families But Losing Children, MiAMI HERALD (Mar. 16, 2014), http://www.miamiherald.com/projects/2014/innocents-lost/stories/overview, archived at http://perma.cc/6SML-83SS.

95. The Jeremiah Oliver case, Abraham, supra note 94, is one in which the great majority of prior allegations involving the family had been for neglect, with many screened out, and the family had a history of such issues. Nonetheless, Jeremiah was killed after going missing for four months without CPS being aware, and the mother and her boyfriend were charged with murder. See CHILD Welfare LEAGue of AM., QuALITY ImPRovement REPORT 9-11 (2014), available at http://www.mass.gov/eohhs/docs/press-release/140528 cwla-final-report.pdf, archived at http://perma.cc/UAS5-ND6V.

96. See, e.g., Innocents Lost: A Miami Herald I-Team Investigation, MiAMI HERALD (Mar. 16 2014), http://media.miamiherald.com/static/media/projects/2014/innocents-lost/, archived at http://perma.cc/GU2S-LAK8. This series helped trigger sweeping child welfare reform legislation in Florida. See Mary Ellen Klas \& Carol Marbin Miller, Florida Senate Moves Forward with Child Welfare Law Overhaul, TAMPA BAY TIMES (Apr. 2, 2014, 10:09 PM), http://www.tampabay.com/news/politics/legislature/florida-senate-moves-forwardwith-child-welfare-law-overhaul/2173291, archived at http://perma.cc/DZX2-89KB (describing that the Innocents Lost Series' influenced Florida to reform its child welfare legislation through an amendment to Florida Senate Bill 1666); e-mail from Judge Jeri Cohen, of the 11th Judicial Circuit, Miami-Dade County, Florida, to author (May 4, 2014, 03:47 PM) (on file with author).

97. Miller \& Burch, supra note 94 (describing the reduction in foster care and in children under CPS supervision at home thought to be responsible for the rising number of child deaths).

98. See, e.g., UMESh DALAL, AUditor's RePORT ON THE Richmond DEPARTMENT OF SOCIAL SERVICES (2013), available at http://bloximages.newyork1.vip.townnews.com/ richmond.com/content/tncms/assets/v3/editorial/8/bc/8bcd4476-b8bd-11e2-8442-0019bb30f31a/ 518bc1cb199c3.pdf.pdf, archived at http://perma.cc/K5P9-GZU7; Robert Zullo, Social Services Director Retires After Scathing Report, RICHMOND TIMES-DISPATCH (May 9, 2013, 6:44 $\mathrm{PM}$, http://www.timesdispatch.com/news/local/city-of-richmond/article_fc5d04b8-b8ba11e2-a6cb-0019bb30f31a.html, archived at http://perma.cc/H5LX-ZFSN.

99. See, e.g., ChILD Welfare League OF AM., supra note 95, at 50 (providing recommendations based on the investigation following Jeremiah Oliver's death); see also Todd Wallack, Report Urges Smaller Caseloads, Closer Scrutiny at DCF, Bos. GLOBE (Mar. 13, 2014), http://www.bostonglobe.com/metro/2014/03/13/report-dcf-needs-more-funding-care- 
Finally, social science provides persuasive evidence of the unduly limited protection offered by CPS. ${ }^{100}$ Among cases reported to CPS hotlines each year, roughly one-third are re-reported within twelve months, ${ }^{101}$ and since reports are thought to be good indicators of actual past maltreatment and good predictors of future maltreatment, this tells us that children are at undue risk. Roughly one-third of children who died from maltreatment were known to CPS prior to their deaths. ${ }^{102}$

Emily Putnam-Hornstein has demonstrated in impressive recent work that for children known to CPS, "high rates of re-reporting and maltreatment recurrence" reveal "widespread system failures to adequately and appropriately respond to child abuse and neglect." ${ }^{103}$ Out of children referred to CPS for maltreatment before their first birthday, $82 \%$ remained in the home, and among those, more than $60 \%$ were referred again before the age of five. ${ }^{104}$ Out of those remaining at home following substantiation of the initial maltreatment allegation, $58 \%$ who received no formal services were re-referred by the age of five, and $65 \%$ of those receiving such services were re-referred by that age. ${ }^{105}$ The net is that CPS almost always keeps children reported for maltreatment at home and then generally fails to protect them from repeated maltreatment, regardless of whether or not it provides services. Earlier research over several decades shows that from one-third to one-half of children who are once identified as abused or neglected and who are kept at home are revictimized within a few years. ${ }^{106}$

The DR research confirms the high risks to children on the traditional CPS track as well as the new AR track, showing that re-report

for-kids/RKkjP7sCqEzFWsXZQfrteK/story.html, archived at http://perma.cc/DLC6-V872 (describing the 2014 interim report triggered by the Jeremiah Oliver case).

100. See generally BARTHOLET, supra note 1, at 98-110 (discussing studies, hearings, and cases that suggest more intervention is necessary).

101. Amy Conley \& Jill Duerr Berrick, Community-Based Child Abuse Prevention: Outcomes Associated with a Differential Response Program in California, 15 CHILD MALTREATMENT 282, 282 (2010); see also KoHL, supra note 29, at 17 (noting that over onethird of children kept at home had re-report or foster placement within thirty-six months).

102. Nancy Peddle et AL., Current Trends in Child Abuse Prevention And Fatalities: The 2000 Fifty State Survey 15 (2002), available at http://www.issuelab.org/resource/current_trends_in_child_abuse_prevention_reporting_and _fatalities_the_1999_fifty_state_survey, archived at http://perma.cc/4DND-59KY.

103. Emily Putnam-Hornstein et al., Strengthening CPS Ability to Protect Infants and Young Children Against Maltreatment 1 (Apr. 2012) (unpublished manuscript), available at http://www.law.harvard.edu/programs/about/cap/cap-conferences/pp-workshop/pp-materials/ 21_strengthening-cps_putnam_hornstein.pdf, archived at http://perma.cc/3XCP-GLUU.

104. Emily Putnam-Horstein et al., Risk of Re-reporting Among Infants Who Remain at Home Following Alleged Maltreatment, Child Maltreatment 1, 2, 9-10 (2014).

105. Id. at 2 .

106. BARTHOLET, supra note 1, at 109; Bartholet, supra note 26, at 1325 n.3. 
rates are extremely high on both tracks, ranging between one-third to two-thirds, depending on the length of the follow-up period. ${ }^{107}$

By contrast, research indicates that removal to foster care serves to protect children from risk. First, the rates of abuse and neglect are tiny in foster care-less than 1\% annually. ${ }^{108}$ Second, Jill Duerr Berrick makes a persuasive case that most research, including the more recent research that attempts to control for important variables, shows foster care removal generally serves children's best interests in terms of such factors as risk of violence to children, child "risk behaviors," child quality of life, and other measures of safety and well-being. ${ }^{109}$

The child-friendly reform move would be to strengthen the CPS system by providing it with significantly more resources and by encouraging increased intervention. That intervention should take the form of expanded supportive services as well as expanded requirements that parents cooperate with rehabilitative services. It should take the form of expanded monitoring and, in the most serious cases, expanded use of the powers to remove children to foster care and to

107. See discussion infra Parts IV.B.1, 2, 4 .

108. Children's Bureau, Admin. For Children and Families, U.S. Dep'T. of Health \& Human Servs., Child Maltreatment 2012, at 50 tbl.3-16 (2013), available at http://www.acf.hhs.gov/sites/default/files/cb/cm2012.pdf, archived at http://perma.cc/BV7YXC52. The comprehensive federal government report on child maltreatment says that half of the states met the standard of $99.68 \%$ for absence of maltreatment (49\% in 2012), and the rest had higher than $99 \%$ absence, except for three states which had absence rates of $98.35 \%$ or higher. Id. Not a single state fell below $98.35 \%$. Id.

109. Jill Duerr BerRick, TAKE Me Home 108-17 (2009). The major exception was one study indicating that in cases considered "marginal," children may do better at home than suffering the disruption and uncertainty that often accompanies foster care placement. Id. at 110-11. While one recent article claims that "numerous studies" show foster care produces more harm, the author cites only two studies, and Berrick's analysis demonstrates that they are of limited relevance. The study Berrick characterizes as the best is one by Taussig, Clyman, and Landsverk. See e-mail from Jill Duerr Berrick, Zellerbach Family Found., Professor, Univ. of Cal. at Berkley, to Daniel Heimpel (Sept. 25, 2013, 01:42 AM) (on file with author). They find, consistent with prior research, significantly worse outcomes for reunified children and conclude:

There was, and continues to be, a pervasive belief that reunification is best for children, despite the lack of research to support this assertion. . . . Evaluation of child welfare policy and practice should be based . . on the impact of . . . [reunification] on behavioral health outcomes for children. . . [A]n often missed voice in the debate about what is in the best interest for children in foster care is the voice of the youth themselves. Studies that have interviewed current and former foster children report that the youth generally had positive feelings about being placed in foster care. Most youth thought it was in their best interest and reported that things would have gotten worse at home without child welfare intervention.

Heather N. Taussig et al., Children Who Return Home From Foster Care: A 6-Year Prospective Study of Behavioral Health Outcomes in Adolescence, PeDiatrics, July 2001, at 6, available at http://pediatrics.aappublications.org/content/108/1/e10.full.pdf, archived at http://perma.cc/ND4W-8KN8 (citations omitted). 
terminate parental rights. England has been moving in just this direction since the highly publicized death of a young child kept at home with his mother and is now celebrating the increase in the number of children adopted out of foster care as a triumph for child well-being. ${ }^{110}$

$\mathrm{DR}$ is, of course, designed to move in the exact opposite direction, diverting the great majority of CPS cases to the voluntary AR system, reducing CPS funding, and as a consequence, reducing all forms of CPS support and intervention.

\section{B. New Risks From Differential Response}

The DR move to divert some $70 \%$ of CPS cases to a purely voluntary track ${ }^{111}$ and to reduce CPS funding dramatically by diverting CPS funds to the DR track, poses obvious and serious risks to child well-being.

\section{Risks from Diversion to Voluntary Track}

\section{(a) Serious Risk Cases on the Voluntary Track}

\section{i. Diverted Cases are Serious Risk by Definition Given Nature of} CPS Caseload

As discussed above, ${ }^{112}$ most cases on the traditional CPS caseload are cases in which children face serious risks. Diverting the great majority of CPS cases to a voluntary track where parents are free to simply walk away-escaping any mandatory monitoring, required rehabilitative treatment, and potential for child removal-poses obvious risks to children. This is why DR advocates have always felt compelled to defend their systems as not likely to increase safety risks. Their arguments are not persuasive.

DR advocates claim that only low-risk cases will be diverted and point to the fact that most CPS cases are in the neglect category as evidence that a majority of cases can be safely diverted. ${ }^{113}$ The simple

110. See, e.g., Angela Harrison, Adoptions Show 'Record' Increase, BBC NEWS (Sept. 26 , 2013), http://www.bbc.co.uk/news/education-24282211, archived at http://perma.cc/PNC8UVE; see also Mary Welstead, Child Protection in England - Early Intervention 2-3 (May 10-11, 2012) (unpublished workshop article) (on file with the Harvard Law School as part of the Prevention and Protection Brainstorming Workshop), available at http://www.law.harvard.edu/programs/about/cap/cap-conferences/pp-workshop/pp-

materials/27_welsteaddoc.pdf, archived at http://perma.cc/5QZL-QJBD (stating how there was public outrage after a child's death in England and that the public called for measures to ensure child safety).

111. See supra note 49 .

112. See discussion supra Part III.A.

113. Amy Conley, Differential Response: A Critical Examination of a Secondary Prevention Model, 29 ChILd. \& Youth Services ReV. 1454, 1456 (2007); C. Nicole Lawrence et 
categorization of a case as neglect is a major factor in DR decisions to track them as AR cases. ${ }^{114}$ But it is frivolous to contend that neglect cases are by definition minor, involving mere poverty or dirty houses. Children in the neglect category are at risk of dying at rates roughly equal to those in the abuse category. ${ }^{115}$ Most neglect cases involve parents addicted to drugs and/or alcohol who are incapable of providing the nurturing parenting that children need, until and unless the parents solve their addiction problems. ${ }^{116}$ Accordingly, child neglect often means the kind of traumatic stress that "literally change[s] the architecture of the child's brain systems in ways that may permanently impair the child's functioning in every domain of development-sensory, emotional, cognitive, and social."117 Many neglect cases involve abuse issues categorized as neglect simply because the latter is easier to prove. ${ }^{118}$

Even assuming that some cases now on the CPS caseload are truly minor and pose limited risk to children, this characterization does not fit a significant percentage and certainly nothing approaching the $70 \%$ DR diversion goal.

\section{ii. Absence of Investigation Means No Ability to Identify Which Cases Are Serious Versus Minor}

DR programs have no way of identifying which cases are truly less risky, warranting diversion to the voluntary track. As discussed above, ${ }^{119}$ DR prides itself on not conducting at the outset, in making the decision of how to track cases, the fact-finding investigation that would be needed to determine which are the high-risk as compared to the low-risk cases. There is no effort to determine whether the alleged maltreatment took place and, if so, who the perpetrator was and what the underlying family dynamics were. Nor is there an investigation once the case is put on the AR track, since any focus on

al., Multiple Response System: Evaluation of Policy Change in North Carolina's Child Welfare System, 33 CHILD. \& YouTH SERVICES REV. 2355, 2355-56 (2011) (showing that neglect cases are generally assigned to the AR track in various DR systems).

114. See, e.g., Hughes et al., supra note 6, at 501 (noting that one state reportedly tracked all neglect referrals to AR).

115. See Fatalities Due to Child Abuse and Neglect, AM. Humane Ass'N, http://www.americanhumane.org/children/stop-child-abuse/fact-sheets/fatalities-due-to-childabuse-neglect.html (last visited Feb. 8, 2015), archived at http://perma.cc/6BWW-W4VP.

116. BARTHOLET, supra note 1 , at 67-68.

117. Frank E. Vandervort et al., Building Resilience in Foster Children: The Role of the Child's Advocate, 32 CHILD. LEGAL RTS. J., 1, 4 (2012); see generally CHARLES A. NELSON ET AL., ROMANIA'S ABANDONED CHILDREN (2014) (reviewing brain science and demonstrating the devastating impact of neglect on early development).

118. See generally, e.g., BARTHOLET, supra note 1, at 65-67 (discussing how neglect cases are extremely serious, and that CPS often use the neglect category because it is easier to prove than abuse).

119. See discussion supra Part II.A.3. 
what the parents might have done to the child is considered inconsistent with the parent-friendly ethic, as is any separate interview of the child or other witnesses.

Common sense alone is enough to make this absence of investigation suspect. If a child has a suspicious burn, asking the child in front of the parent whether the burn resulted from an accident or from a parent's deliberate application of a hot iron is not likely to produce an honest answer, if the child is indeed at risk of violence from the parent. If police respond to an emergency call involving domestic violence and find a woman injured and weeping, would anyone today think it appropriate to insist that no separate interview of the woman be conducted and that, instead, the man and woman be kept together for a family-friendly assessment of future risks so as to decide on the appropriate response?

Professional expertise confirms that fact-finding investigations designed to figure out what actually took place in connection with the alleged maltreatment-including separate interviews of the child in a safe-feeling neutral space-are key elements of an appropriate assessment of future risk to the child. ${ }^{120}$ Several workshops at a recent colloquium given by the leading professional association on child maltreatment, the American Professional Society on the Abuse of Children (APSAC), emphasized the importance of such investigations and revealed the degree to which separate interviews of the child are the accepted professional mantra. ${ }^{121}$ Michigan has a law requiring that children be interviewed separately. ${ }^{122}$

Many in the child welfare field have emphasized in recent years the importance of increasing the depth and scope of traditional CPS investigations, enabling CPS workers to make better decisions as to the appropriate response. They note the importance of including the "history of child maltreatment" in that assessment. ${ }^{123}$ They promote the use of multidisciplinary teams that "interview and examine fami-

120. See, e.g., Hughes et al., supra note 6, at 501 ("[F]ormal risk assessmentsparticularly the more reliable and valid actuarial risk assessments-are difficult to complete fully or accurately without face-to-face family contact and a deeper exploration of a family's circumstances, including the presence and dynamics of previous maltreatment." (internal citation omitted)); Vaughan-Eden \& Vandervort, supra note 39, at 551 ("Obviously, one primary problem is that CPS cannot know which families will fall into this [risk] category until it has conducted an investigation. . . . [A]bsent such an investigation, children's safety cannot be assured.").

121. See, e.g., Julie Kenniston \& Rita Farrell, First Responder Interviews: Called by So Many Names, but How Should I Really Be Doing Them?, AM. Prof'L Soc'y on the Abuse OF CHILD. (May 22, 2014), http://www.apsac.org/assets/documents/2014_Colloquium/ 2014_Handouts/32\%20workshop.pdf, archived at http://perma.cc/EJZ3-E3BP.

122. Мich. COMP. LAWs $\S 722.628 \mathrm{c}(2014)$.

123. Vandervort et al., supra note 117 , at 8. 
ly members in an effort to determine the likelihood, nature, and/or extent of child maltreatment and develop an intervention plan." 124

The Federal Government has weighed in on the need for more careful, in-depth factual assessments. The Children's Bureau has said that "[a]ssessment forms the foundation of effective practice with children and families["125 and found in its most recent Child and Families Services Review that CPS agencies were too often "not sufficiently comprehensive to capture underlying family issues, such as substance abuse, mental illness, and domestic violence, that may contribute to maltreatment." 126

Many child welfare systems have sought to provide increasing protection to children by combining civil child protection services with law enforcement approaches, enabling more thorough investigations and more comprehensive responses. ${ }^{127}$ One prosecutor expressed her concern with the move to adopt DR as follows:

I am deeply disturbed by the impact this will have on our ability to protect children. ... With DR, ... child services are now prohibited from sharing information with law enforcement, and prosecutors. This will have a terrible impact on our ability to protect the children that fall within ... [the DR] category . . . ${ }^{128}$

This is not to say that the full forensic investigation thought appropriate in criminal child abuse cases is required in all child welfare cases. But a meaningful inquiry into the facts that enables child welfare workers to know what happened in the past, so as to illuminate future risk, is required.

The social science supports common sense and professional expertise in making the absence of a fact-finding investigation troubling. There is a general consensus among serious students of the child welfare system, based on extensive evidence, that the best predictor

124. Kathleen Coulborn Faller et al., Can Early Assessment Make a Difference in Child Protection? Results from a Pilot Study, 2 J. of Pub. ChILd Welfare 71, 73 (2008).

125. Family-Centered Assessment, CHILD WELFARE INFO. GATEWAY, https://www.childwelfare.gov/famcentered/caseworkpractice/assessment.cfm (last visited Feb. 8, 2015), archived at http://perma.cc/M7VB-2UB9.

126. Diane DePanfilis, U.S. DeP’t of Health \& Human Servis., Child Neglect: A Guide fOr Prevention, Assessment, AND Intervention app. D, at 102 (2006), available at https://www.childwelfare.gov/pubs/usermanuals/neglect/neglect.pdf, archived at http://perma.cc/X78X-FXNF.

127. The CAPTA requires this as part of the state's plan in order to receive federal funding. See Keeping Children and Families Safe Act of 2003, Pub. L. No. 108-36, 117 Stat. 800 (codified as amended at 42 U.S.C. $§ 5106($ a) (2006)).

128. E-mail from Christine O. Corken, Attorney, First Assistant, Dubuque Cnty., to author (Mar. 21, 2014, 2:46 PM) (on file with author). 
of whether child maltreatment will occur in the future is whether it has occurred in the past. ${ }^{129}$

AR's failure to make factual findings documenting in CPS files that maltreatment has occurred and its failure to list perpetrators on maltreatment registries pose additional safety issues. If children are reported in the future as being victimized again, social workers and others will be denied the best evidence of the need for protective intervention. As but one indication of the problem, the federal government monitors state child welfare systems for maltreatment recurrence and uses as a measure of recurrence the substantiation of maltreatment after a previous substantiated report. By definition, any maltreatment that parents on the AR track are responsible for will not be substantiated; and accordingly, any subsequent maltreatment, even if substantiated, will not count for purposes of this federal measure of child safety. ${ }^{130}$

\section{iii. Evidence to Date Indicates Serious Risk Cases Are in Fact \\ Diverted to the Voluntary Track}

There is increasing evidence in the research on DR that many of the cases diverted to the AR track are, in fact, characterized by serious rather than minor risk. One California DR study found that almost half of the AR sample cases analyzed in the program were either "high risk" or "very high risk," despite the claimed goals of diverting only low-risk cases. ${ }^{131}$

129. Rosemary Chalk, Background Paper: Major Research Advances Since the Publication of the 1993 NRC Report Understanding Child Abuse and Neglect: Highlights from the Literature, in IOM/NRC 2012 RESEARCH WORKSHOP SUMMARY, supra note 3, at 158. The Children's Research Center, responsible for the extensive work on Structured Decision Making, found based on years of research designed to build reliable risk assessment instruments that prior maltreatment was the most relevant risk factor in estimating the likelihood of future maltreatment. See e-mail from Judith S. Rycus, Program Dir., Inst. of Human Servs., N. Am. Res. Ctr. for Child Welfare, to Frank E. Vandervort, Clinical Professor of Law, Univ. of Mich., and Daniel Heimpel (June 1, 2014, 11:55 PM) (on file with author); see also Daniel Heimpel, Not for Your Consideration, The Chronicle of Soc. CHANGE (June 3, 2014), https://chronicleofsocialchange.org/news/not-for-yourconsideration/6875?print=1, archived at http://perma.cc/3B32-WS4A (quoting experts to the effect that prior maltreatment and reports of same are the best predictors of future maltreatment).

130. See Mgmt. Audit Comm., Dep’t of Family Servs., Wyoming Child Protective SERVICES 26 (2008) available at http://legisweb.state.wy.us/progeval/reports/ 2008/CPS/CPSfullreport.pdf, archived at http://perma.cc/6W85-8NCV; U.S. DEPT. OF HEAlth AND Human SERVICES, ADMINISTRATION FOR CHILDREN AND FAMILIES, CHILDREN'S Bureau, Child Maltreatment 1998: Reports From the States to the National Child AbUSE AND NEGLECT DATA SYSTEM, ch. 1.2 (1998), available at http://archive.acf.hhs.gov/programs/cb/pubs/cm98/cpt1.htm, archived at http://perma.cc/ RB5Q-9P87;.Piper, supra note 55, at 9-10.

131. Conley \& Berrick, supra note 101, at 289. 
Even the advocacy research that purports to find DR successful documents the serious risk characterizing many cases on the AR track. A 2010 Ohio study found that almost half of the AR cases had at least one past report of abuse and neglect, and almost $15 \%$ had four or more prior reports. ${ }^{132}$ A recent Colorado study noted that $76 \%$ of the $\mathrm{AR}$ cases were medium risk and $10 \%$ were high risk. ${ }^{133}$

The research also shows that ongoing maltreatment rates on the $A R$ tracks are extremely high. The California study noted above reveals a one-third re-report rate within the brief nine-month $A R$ treatment period. ${ }^{134}$ Even the lead authors of the early advocacy research supporting DR, Tony Loman and Gary Siegel, note the "high rates of recidivism." ${ }^{135}$ Their 2014 Ohio Report shows that roughly half of all AR families received at least one subsequent family risk assessment. ${ }^{136}$ Their 2004 Minnesota Report says the overall rereport rate is about one in three families during a relatively short tracking period of two to three years. ${ }^{137}$ It predicts that long-term rates would rise to something like the general CPS recurrence rate of $65 \% .{ }^{138}$ In an interview, Tony Loman indicated that typically in his DR research, he found an unduly high re-report rate, noting that in the Missouri DR program, the rate was 50\% to $60 \%$ after five to seven years. ${ }^{139}$

And while the DR system is supposed to have a method for sending high-risk cases back from the AR to the TR track, this rarely happens as discussed above-available evidence indicates that only a tiny percentage of AR cases are sent back to the TR track based on social worker reevaluation of safety risk. ${ }^{140}$ Richard Barth, a highly

132. L. Anthony Loman et AL., Inst. of ApPlied Research, OHio Alternative RESPONSE EVALUATION FINAL REPORT 42 fig.4.6 (2010), available at http://www.iarstl.org/papers/OhioAREvaluation.pdf, archived at http://perma.cc/8SA5-AD87.

133. See, e.g., WINOKUR ET AL., supra note 56, at 41 tbl.4.3.

134. Conley \& Berrick, supra note 101, at 286.

135. L. Anthony Loman \& Gary L. Siegel, Effects of Anti-Poverty Services Under the Differential Response Approach to Child Welfare, 34 CHILD. \& YouTH SERVICES REV. 1659, 1666 (2012). For discussion of Loman's and Siegel's roles in the DR movement, see discussion infra Part IV.

136. See L. Anthony Loman \& Gary L. Siegel, Inst. of Applied Research, Ohio ALternative RESPONSE EvAluAtion EXTENSION: FINAL REPORT viii (2014), available at http://www.americanhumane.org/assets/pdfs/children/differential-response/pc-dr-ohiosection2-final-evaluation-report-1.pdf, archived at http://perma.cc/ZAP7-7CZ4 .

137. LOMAN \& SIEGEL, supra note 136, at 141-42.

138. Id. A recent Loman and Siegel Ohio study reveals that nearly half of the families in the combined group of AR and TR cases had one or more screened-in re-reports. Loman \& Siegel, supra note 61 , at 8 .

139. Telephone Interview with L. Anthony Loman (Oct. 18, 2013). L. Anthony Loman is a research director at the Institute of Applied Research in St. Louis, Missouri.

140. See discussion supra Part II.A.2 (noting that only $0.3 \%$ to $5.6 \%$ of child welfare cases in the states and counties assessed are moved from an AR track to a TR track based on such reevaluation). 
respected child welfare expert, says that unless AR cases are referred back "a substantial amount of the time (25\% perhaps), then the system isn't working." 141

\section{(b) Voluntary Track Inappropriate for Serious Risk Cases}

\section{i. Need for Monitoring, Supportive and Rehabilitative Services, and for Protective Intervention Authority}

DR proponents claim that voluntary will work better than coercive, because parents will respond to the parent-friendly approach by cooperating with services. They bolster their case by pointing to the research that allegedly shows AR track parents receive more services and appear to be more positively engaged with their workers than TR track parents.

But there is every reason to think that the children on the AR track in the cases involving serious risk are more likely to suffer ongoing maltreatment because of the entirely voluntary nature of the system.

First, as discussed above, most parents charged with maltreatment have fallen into serious dysfunctional patterns that often include a combination of substance abuse and addiction, domestic violence, and mental illness. ${ }^{142}$ Few will be able to escape those patterns on their own volition. While there are limited helpful studies of the comparative benefits of voluntary versus coercive programs, some evidence in the area of substance abuse treatment indicates that coercion works better. ${ }^{143}$ Tellingly, in the 2004 Minnesota DR study, when AR workers were asked which parents were least likely to benefit from AR, the most common response was parents involved in substance abuse. ${ }^{144}$

141. E-mail from Richard Barth, Dean, University of Maryland School of Social Work, to author (July 1, 2014, 9:35 PM) (on file with author). Barth served as a consultant to the IOM/NRC project discussed below, and its report cites his concerns regarding the low switch rate. See discussion infra Part IV.B.2.

142. See supra Part III.A.

143. See, e.g., BARTHOLET, supra note 1, at 219, 286-87 n.21 ("[S]uch research as exists indicates that coercive pressure is in fact useful."); Bartholet, supra note 26, at 1337 n.43 (citing family drug court expert comments at the Prevention and Protection Workshop held at Harvard Law School on May 11, 2012); see also Piper, supra note 55, at 27 (stating that most studies show mandatory programs work better than voluntary ones for substance abuse treatment enrollment and retention but not for long-term abstinence, and also noting that these studies involve non-equivalent comparison groups making conclusions regarding effectiveness problematic).

144. L. Anthony loman \& Gary L. Siegel, Inst. of Applied Research, Minnesota Alternative Response Evaluation: Final Report 68 (2004), available at http://www.iarstl.org/papers/ARFinalEvaluationReport.pdf http://perma.cc/6GTV-SLKZ. 
Second, once parents are identified as maltreating their children, research shows that services are unlikely to enable them to recover from their problems sufficiently to avoid ongoing maltreatment. ${ }^{145}$ The traditional CPS system's authority to impose monitoring by social workers, to require cooperation with rehabilitative treatment, and in the most serious cases, to remove children and terminate parental rights, enables it to protect children when parents pose ongoing threats to child safety and well-being. ${ }^{146}$

\section{ii. The Dropout Problem: Highest Risk Cases Most Likely to Drop \\ Out}

In addition, we know that the highest-risk parents are those most likely to drop out and that they will drop out at very high rates. This means that they will not receive the AR track services and will not engage with the AR workers in the ways meant to assure us that the risk of maltreatment will be reduced. It means that they will escape any monitoring by AR social workers and any attention by workers connected with AR-related social service programs that might provide the potential for child maltreatment being noticed and reported. All of this means, in turn, that their children will have seriously reduced opportunities for protective intervention in the event that their safety and well-being are threatened.

The research on Early Home Visitation has taught us enough to be concerned about the potential DR dropout problem. Home Visitation programs have similar goals to DR, including the reduction of child maltreatment. They serve similarly troubled populations, offer a range of supportive services, and operate on a similar voluntary model, with parents free to reject participation without consequence. ${ }^{147}$ They have been studied extensively for decades. The best of the programs, with the best evidence of success in helping to reduce the risk of maltreatment, have extremely high dropout rates-between one-third and one-half of all those parents targeted. ${ }^{148}$

A thorough 2014 report on Early Home Visitation by Mathematica Policy Research and Chapin Hall at the University of Chicago ${ }^{149}$ re-

145. BARTHOLET, supra note 1, at 109-10; Bartholet, supra note 26, at 1337-38; Harriet L. MacMillan et al., Effectiveness of Home Visitation by Public-Health Nurses in Prevention of the Recurrence of Child Physical Abuse and Neglect: A Randomised Controlled Trial, 365 LANCET 1786, 1792 (2005) (showing that a model home visitation program, promising in reducing the likelihood of maltreatment among first-time parents, had no success in reducing maltreatment among parents once identified as having victimized their children).

146. See Bartholet, supra note 26, at 1337-38.

147. BARTHOLET, supra note 1, at 163-75.

148. See BARTHOLET, supra note 1, at 169-70, 277 n.17, 1353 n.85.

149. See generally Kimberly Boller ET AL., MAKing REPLiCATION Work: BuILDing INFRASTRUCTURE TO IMPLEMENT, SCALE-UP, AND SUSTAIN EVIDENCE-BASED EARLY Childhood Home Visiting Programs with Fidelity (2014), available at 
veals the extent of the problem. Dropout rates for the long-term programs ranged from $27 \%$ to $42 \%$ at the twelve-month stage. ${ }^{150}$ Families typically received only half of the home visits expected. ${ }^{151}$ In the very successful Nurse Family Partnership program, only $45 \%$ to $62 \%$ of the planned visits were achieved. ${ }^{152}$ The report summarizes that just over half of the families in all of the studied home visitation programs remained in services for at least twelve months, and about two-thirds of the families in the three long-term programs remained in services, noting that these rates are consistent with, and may exceed, participation rates reported in previous research. ${ }^{153}$

Moreover, this report shows that the Home Visitation dropouts are disproportionately those parents most at risk of maltreating their children. ${ }^{154}$ The reasons given for dropping out from Early Home Visitation programs are very significant in understanding $D R$ safety risks. Among the primary reasons are "drug abuse, [or] fear [that a] home visitor will observe child abuse or illegal behavior." 155

DR advocacy research has avoided any focus on the troublesome dropout problem. But careful reading of this research reveals what is to be expected: a very high dropout rate with the dropouts apparently characterized as particularly high risk. For example, the 2011 New York DR Report says that $31 \%$ of the AR track parents were willing to listen but did not act on the worker's recommendations or service offers, and another $6 \%$ were completely uninterested or dismissive. ${ }^{156}$ A Minnesota CPS spokesperson says that only half of the state's AR track parents chose to participate. ${ }^{157}$

Moreover, the recent $Q I C-D R$ research, discussed below, ${ }^{158}$ demonstrates both the high rate of dropouts and the high-risk nature of these dropouts. This is the only DR research to focus any attention on this issue.

\footnotetext{
http://www.chapinhall.org/sites/default/files/documents/EBHV_MakingReplication_Final.pdf, archived at http://perma.cc/F35T-54MM (reporting on early child home visiting programs).

150. See id. at 38 tbl.III.5.

151. Id. at 79 .

152. Id.

153. Id. at 80 .

154. Id. at xvi ("Higher-risk families were more likely to leave the program early."); see also id. at xviii (finding that families with the most challenges were most likely to leave the program). Those identified as high risk are the same as those regularly identified as having the greatest risk for maltreatment: younger, more economically disadvantaged, and more socially isolated participants, including single parents. $I d$. at 25,80 .

155. Id. at 39,80 .

156. RUPPEL ET AL., supra note 5, at 58.

157. Brandon Stahl, Counties 'Screen Out' Most Child Abuse Reports, STAR TRIBUnE (Apr. 20, 2014, 11:48 PM), http://www.startribune.com/local/255888251.html, archived at http://perma.cc/9KKZ-H5J3.

158. See discussion infra Part IV.B.4.a.
} 


\section{Risks From Reducing Financial Support for Traditional CPS}

DR proponents claim that by removing the low-risk cases to the voluntary track, CPS will be able to provide better protection to the children at the highest risk.

But this claim is belied by the DR finance reform agenda. The strategy for financing DR relies on significantly reducing federal foster care funding and CPS resources more generally, so that in fact CPS would have greatly reduced capacity to protect the children on its caseload. ${ }^{159}$

The child-friendly reform move would be to expand resources for CPS. These resources have shrunk in recent years because of the 2008 recession and related federal, state, and local budget cuts. ${ }^{160}$ This has had its own impact on child safety.

Further reducing funds for the resource-starved CPS system will put children at a newly frightening level of risk. Common sense supported by available evidence suggests that CPS will do a better job protecting children if it is given adequate resources to pay its social workers, reduce caseloads, conduct investigations, provide services, collect evidence, take cases to court as necessary to remove children, place and maintain them safely in foster care, and in appropriate cases terminate parental rights. ${ }^{161}$

There is already some evidence that DR is adversely affecting child safety because of this diversion of funds from CPS. In Connecticut, a court monitor supervising the child welfare system reported in the fall of 2013: " Front line staffing levels are inadequate given the complexity of cases that now make up the pool of investigation and ongoing service cases that social workers have on their caseloads since the implementation of the Differential Response System.' "162 Research reports document CPS worker complaints that they are overburdened as a result of the diversion of resources to AR. ${ }^{163} \mathrm{Con}$ cerns about how this diversion has threatened the safety of children

159. See discussion supra Part II.B.

160. Memorandum from Sean Hughes, supra note 11, at 32.

161. See, e.g., Cross et al., supra note 50, at 35 (stating that limited CPS resources are associated with lower substantiation rates, lower ongoing services rates, and lower child placement rates); Faller et al., supra note 124, at 73 (noting that because of the paucity of resources, CPS screens out children needing services, conducts narrowly focused investigations, denies cases in which children need help, and closes cases right after substantiation); Jenifer McKim, A Wave of Infants Lost in DCF Families, Bos. GloBe (July 13, 2014), http://www.bostonglobe.com/metro/2014/07/12/babies-under-department-children-andfamilies-supervision-suffer-sleep-related-deaths-alarming-rate/kQ5BbcvJFmzUfV6KH6 IzDN/story.html, archived at http://perma.cc/Y7WJ-HXUK.

162. Heimpel, supra note 7 (quoting CourT Monitor RAYMOND MANCUSCO, JUAN F. v. MALlOY EXIT PLAN QUARTERLY REPORT 4 (2013), available at www.ct.gov/dcf/lib/ dcf/positive_outcomes/pdf/2nd_qtr_report_2013_final_(2).pdf)).

163. See discussion infra Part IV.B.4.b. 
on the CPS caseload have been a factor leading a number of states to eliminate their DR programs. ${ }^{164}$

One proffered rationale for this federal finance move is an old chestnut in the family preservation arsenal. DR proponents claim that a disproportionate amount of federal funding goes to removing children from their parents for maltreatment as opposed to preventing maltreatment in the first place. ${ }^{165}$ One problem with this argument is that the calculus is based on false factual assumptions-on the omission of many very significant federal sources of funds for prevention. Casey and others typically rely on a comparison between the Title IV-E funds provided by the federal government for foster care and the IV-B funds provided for prevention services, as if this proved their case. ${ }^{166}$ But this entirely ignores all of the federal funds provided for prevention services through welfare and other programs. ${ }^{167}$

Also, Casey poses a false choice between funding for prevention services and funding for children in out-of-home care. This is the choice only if finance reform is done cheaply, in a budget-neutral way, with no new resources dedicated to child welfare. Breaking with long-standing tradition among child welfare advocates, Casey has repeatedly declined to call for new funding, instead assuring policymakers that finance reform can and should be done at no cost to the federal government. ${ }^{168}$

Casey's position is, of course, completely consistent with its 2020 foster care reduction goal. Casey believes that reducing funding for foster care will create compelling fiscal incentives for states to limit foster care usage.

Another problem with the rationale for DR finance reform is that DR has little to do with true maltreatment prevention. There is some evidence that prevention programs like Early Home Visitation actually work to prevent maltreatment from occurring in the first place. ${ }^{169}$

164. See infra Conclusion.

165. See generally William C. Bell et al., Guest: Strengthen Investment in Families to Help Foster Children, SEATTLE TIMES (June 5, 2013), http://www.seattletimes.com/ opinion/guest-strengthen-investment-in-families-to-help-foster-children/, archived at http://perma.cc/9S2R-4L9D (discussing how more funds ought to be taken from foster care services and put into early intervention services).

166. Casey Family Foundation, Moving Toward Hope: Paths to Keep Children SAFe, MaKe FAmilies Strong ANd Build Supportive Communities 9-10 (2013).

167. See Memorandum from Sean Hughes, supra note 11, at 34-38 (providing the following list of funding sources for prevention services: Temporary Assistance for Needy Families (TANF); Social Services Block Grants; the Maternal, Infant, and Early Childhood Home Visiting Program; Medicaid; and the CAPTA).

168. See Memorandum from Sean Hughes, supra note 11, at 39.

169. See, e.g., BARTHOLET, supra note 1, at 166-68 (describing the promising research on Early Home Visitation programs); Bartholet, supra note 26, at 1347 n.69 (citing more recent Home Visitation research). 
But DR operates after maltreatment has occurred and is designed to keep children identified as victims of abuse and neglect with their parents, free from any CPS intervention. There is little evidence showing the success of supportive service programs targeted at families in which abuse and neglect has already occurred, and indeed, there is extensive evidence that most of them fail. Such children are re-victimized at rates ranging between one-third and one-half when kept at home or returned home from foster care. ${ }^{170}$

We must continue to provide services to families in which there is significant reason to hope that parents who have committed maltreatment can do what it takes to become fit and nurturing. We should, indeed, clearly expand such funds. Federal finance reform designed to provide additional funds for at-home services would be an important step in enabling these efforts. But we should do this within the context of the CPS system so that it can act to protect children as necessary, using its authority to monitor families, require cooperation with treatment plans, remove children to foster care, and terminate parental rights.

\section{RESEARCH ISSUES IN DIFFERENTIAL RESPONSE: THE CORRUPT MERGER OF ADVOCACY WITH RESEARCH}

The research picture reflects the problematic pattern of prior history, as discussed above. ${ }^{171}$ First, most of the research is designed to justify moving in the DR direction, rather than to honestly assess whether DR serves child interests and other important goals. It is designed to persuade policymakers to adopt DR, rather than to enable them to decide whether they should do so. This research, referred to here as the "advocacy research," purports to take child safety into consideration, but it is not actually designed to assess DR in terms of child safety or broader measures of child well-being. It ignores issues that would be an obvious focus for attention if the goal really were to assess DR's impact on children.

Second, most of the research is produced by people and organizations with powerful links to those promoting DR rather than by independent social scientists who are free to pursue the objective facts that should be of greatest interest to policymakers.

One group of core organizations and individuals has been heavily involved in both the promotion of DR and the research purporting to assess its value. ${ }^{172}$ This group includes Casey Family Programs, the AHA, the Kempe Center for the Prevention and Treatment of Child

170. See BARTHOLET, supra note 1, at 109; Bartholet, supra note 26, at 1325 n.3; discussion supra Part III.A.

171. See discussion supra Part I.

172. See supra Introduction. 
Abuse and Neglect, and the Institute of Applied Research (IAR). The AHA, long active in promoting $\mathrm{DR},{ }^{173}$ also received with the IAR a grant to supervise the important research project conducted by the Quality Improvement Center on Differential Response (QIC-DR). ${ }^{174}$ The AHA later relinquished its QIC-DR role to the Kempe Center, which also played a role in the earlier DR research. ${ }^{175}$ The QIC-DR research was designed to be the culminating research phase that would provide the basis for persuading the federal government to make a major shift of funds from CPS to DR. IAR senior analysts Tony Loman and Gary Siegel had been responsible for most of the earlier, highly influential DR advocacy research; ${ }^{176}$ they also worked as influential consultants to the QIC-DR. ${ }^{177}$

Casey Family Programs has played a key role in promoting DR, in supporting DR with funding grants, ${ }^{178}$ and in the DR advocacy research picture. It has put out advocacy documents, which make an avid pitch for the DR approach, while claiming at the same time that $\mathrm{DR}$ is supported by the research. These read as some combination of classic advocacy and research. One such document is "The Differential Response (DR) Implementation Resource Kit," apparently designed to persuade new jurisdictions to adopt DR and to help them implement it. ${ }^{179}$ This Implementation Kit provides a totally positive view of the research, entirely ignoring the devastating critique of DR research published by Hughes and Rycus and the related debate triggered, which is discussed below. ${ }^{180}$ It also ignores any discussion of other independent research critical of DR. ${ }^{181}$ Instead, the Implementation Kit makes the unqualified claim that DR "has demonstrated improvements in family engagement, worker satisfaction, and community satisfaction and cooperation, while maintaining child safety." 182 Another such Casey product is the "breakthrough series collaborative" report on DR in California. ${ }^{183}$ This report talks of Cali-

173. See RUPPEL ET AL., supra note 5, at 13; Memorandum from Sean Hughes, supra note 11 , at 26 .

174. WINOKUR ET AL., supra note 56, at ix.

175. Memorandum from Sean Hughes, supra note 11, at 26.

176. See discussion infra Part IV.B.1.a.

177. See discussion infra Part IV.B.4.b.

178. For example, Casey Family Programs helped support the Ohio pilot DR program. See Puckett, supra note 1. Casey also provided funds for the New York program, as did the Marguerite Casey Foundation. RUPPEL ET AL., supra note 5, at 17. See also Introduction for Casey Family Programs' central role in DR.

179. See GUTERMAN ET AL., supra note 7, at 4.

180. See discussion infra Part IV.B.3.

181. See discussion infra Part IV.B.2.

182. GUTERMAN ET AL., supra note 7, at 5.

183. See generally CASEY FAMILY PROGRAMS, supra note 13 (overviewing the Casey breakthrough collaborative with California on DR). 
fornia's "compelling vision" involving DR and claims it is "grounded in research and backed by an outcomes-based accountability system . ..."184 The report paints a rosy picture throughout.

The problematic merger of policy advocacy with research is further illustrated by the DR conference sponsored by the Kempe Center in October 2013. ${ }^{185}$ The conference brochure features DR as a success story. ${ }^{186}$ The conference title is "Differential Response: A Catalyst for Change." 187 The introduction claims: "Research and implementation experience has shown that, when CPS implements two response pathways, practice across the child welfare system improves." 188 The opening keynote features a Casey Family Programs staff member, and is titled: "What Families Tell Us They Need: Working Together to Keep Them Strong and Their Children Safe." ${ }^{189}$ A closing breakout session features two Casey Family Programs staff members on "Differential Response: A Review and Summary of the Research Evidence." ${ }^{90}$ This session is summarized as follows: "Differential response stands out among child welfare practice approaches because of the research evidence of its effectiveness . . .."191

Maryland's recent decision to adopt DR represents another example of this advocacy-research merger. ${ }^{192}$ Casey Family Programs helped stock the state's advisory council meetings with consultants, co-sponsored trips to educate Maryland CPS staff about DR programs, distributed reports citing IAR positive research findings, and then helped IAR get the contract to evaluate Maryland's new DR program. ${ }^{193}$

\section{A. What Child-Friendly Research Would Look Like}

Appropriate child welfare research would focus on child welfare and would be child-friendly. This would mean analyzing the pros and cons of DR in terms of child safety and well-being.

184. Id. at i.

185. Registration Brochure, Differential Response: A Catalyst for Change, The Kempe Center's 8th Annual Conference on Differential Response in Child Welfare 1 (Oct. 22-25, 2013), http://www.ucdenver.edu/academics/colleges/medicalschool/departments/pediatrics/ subs/can/DR/Documents/DR\%20Conference\%20Registration\%20Brochure.pdf, archived at http://perma.cc/64TG-9USM.

186. Id. at 3-16.

187. Id. at 1 .

188. Id. at 2 .

189. Id. at 5 .

190. Id. at 15 .

191. Id.

192. Heimpel, supra note 15.

193. Id. 
Child-friendly research would mean, first, assessing overall whether we should move in the DR direction or in just the opposite direction, providing more resources to CPS so that it can do a better job of protecting children. All agree that there are problems with the current system in terms of its failure adequately to protect children. There has long been a debate about whether to move in the direction of greater or lesser intervention by CPS. We could learn a lot that would be helpful in designing a more child-friendly system by comparing how children do (1) when new resources are devoted to a voluntary track providing supportive services to families, as compared to (2) when CPS is given equivalent new resources to support families as well as protect children. Such research would help test the dubious DR assumption that an entirely voluntary system oriented primarily toward providing support will work better for children than a system with authority to monitor child safety, require that parents cooperate with rehabilitative services, and remove children as needed for their protection.

Second, given the high re-report rates on families on both $\mathrm{AR}$ and TR tracks, ${ }^{194}$ child-friendly research would focus on the dangers to children on both tracks and on how we might better protect them. Again, this argues for assessing how CPS would do if it were provided additional resources.

Third, child-friendly research would focus on the obvious risks DR poses for children to see whether those risks are real. Such research would focus on developing methods for accurately assessing the seriousness of the cases diverted to the AR track. It would focus on the high dropout rate and develop measures for assessing the maltreatment rate along with other indicators of child well-being in this dropout population. It would not rely on re-report rates as indicators of the extent of actual maltreatment suffered on the AR track, given the many reasons for concluding that such reports underestimate maltreatment and fail to accurately reflect differences between rates on $\mathrm{AR}$ and TR tracks, including that parents dropping out are subject to less surveillance by mandated and other potential reporters. ${ }^{195}$

Finally and most importantly, appropriate child-friendly research would follow the tradition of true scientific research. It would be conducted by social scientists with no commitment or bias to finding a success story in DR. Indeed, without such people designing the research, it is impossible to know all of the questions that good research would investigate and to identify all of the flaws in existing research.

194. See discussion supra Part III.A, infra Parts IV.B.1.d, IV.B.2, IV.B.4.a.i.

195. See discussion infra Parts IV.B.1.d, IV.B.2. 


\section{B. Existing Research}

\section{The Early Advocacy Research}

\section{(a) Promotional Nature \& Tone}

One organization, the IAR, and its two senior analysts, Tony Loman and Gary Siegel, are responsible for most of the influential early DR research. ${ }^{196}$ They produced a series of positive reports touting DR as a success story. ${ }^{197}$ These reports have been the primary basis for DR proponents' claims that DR is an evidence-based program that the nation's child welfare systems should embrace.

IAR's 1997 Report on Missouri's DR program helped to fuel the early DR movement, claiming marginally lower rates of child maltreatment recurrence in DR counties, and thus supporting the idea that DR was consistent with child safety. ${ }^{198}$ IAR's 2004 evaluation of Minnesota's DR program was also very influential. ${ }^{199}$ IAR followed with many other reports, including one on Ohio, ${ }^{200}$ where Casey Family Programs and the AHA had been heavily involved in DR's development. ${ }^{201}$ The IAR research model also influenced DR research conducted by others. ${ }^{202}$

Only a few of the early studies used random assignment: Missouri, Minnesota, Ohio, and New York. ${ }^{203}$ Each of these studies was conducted by IAR except New York, which followed the IAR research model. ${ }^{204}$

196. See WINOKUR ET AL., supra note 56, at $1 \mathrm{nn} .1-6$ (listing then key research reports, with five of the six authored by Loman and Siegel). See also Papers \& Reports, InST. OF APPLIED RESEARCH, http://www.iarstl.org/papers.htm (last visited Feb. 10, 2015), archived at http://perma.cc/M452-9QG7, for the many DR research studies they have conducted over the years.

197. Id.

198. Gary L. Siegel et Al., Inst. of Applied Research, Missouri Family Assessment AND Response Demonstration: Final Evaluation Report 96 tbls.5.5 \& 5.6, 105-06, 212 (1997), available at http://www.iarstl.org/papers/MO\%20 FAR\%20Final\%20Report-for\%20website.pdf, archived at http://perma.cc/76SN-YZQV.

199. See generally LOMAN \& SIEGEL, supra note 144 (reporting on their evaluation of Minnesota's DR program that involved randomized assignment); Heimpel, supra note 15.

200. See generally LOMAN ET AL., supra note 132 (reporting on their evaluation of Ohio's DR program). An updated report was released in 2014. See generally L. ANTHONY Loman \& Gary L. Siegel, Inst. of Applied Research, Ohio Alternative Response EVALUATION EXTENSION: FINAL REPORT (2014), available at http://www.iarstl.org/ papers/OhioARFinalExtensionReportFINAL.pdf, archived at http://perma.cc/W4EU-E5BQ (updating previous report on Ohio's DR program).

201. See Tim Morrison \& Noah Dzuba, Differential Response - Draft Report 10 (July 15,2014 ) (unpublished manuscript) (on file with author). See Papers \& Reports, supra note 196 , for the various IAR reports.

202. See, e.g., RUPPEL ET AL., supra note 5, at 31-40 (employing a model to study DR in New York similar to IAR reports).

203. MERKEL-HOLGUIN ET AL., supra note 2, at 42, 69.

204. Id. at $21,42,69$. 
The fact that two people associated with one organization have received repeated contracts for producing a series of positive research reports is a problem in itself. A significant percentage of all papers and reports listed on the IAR website focus on DR. ${ }^{205}$ IAR, by definition, has an economic bias in favor of churning out repeat versions of the DR success story. It seems unlikely that it would have received repeat contracts if its reports had challenged any key DR movement premises. IAR co-authors Loman and Siegel support DR advocacy efforts with unabashed enthusiasm. For example, Siegel is quoted in the Casey Family Programs Implementation Resource Kit, equating DR with a precociously brilliant child. ${ }^{206}$ Supporting the creation of new DR management positions, he says: "Every child needs a parent, even a child prodigy." 207 This is not the language you would expect an objective social scientist to use about a program he is responsible for evaluating.

The research reports read like advocacy, not independent, neutral social science. There is, for example, no section at the end of the reports discussing "limitations" to warn the reader of the limits of the research and conclusions that can fairly be drawn or alert the reader to further research that would be useful in answering important open questions. The reports regularly include rave reviews of DR. The 2004 Minnesota Report opens its description of study highlights with the unqualified claim: "Child safety was not compromised" by the AR approach. ${ }^{208}$ Its introduction states: "As states seek ways to make child protection systems more effective, a new paradigm has emerged with potential to be a major system reform within child protection." 209 The reports regularly argue for expansion of DR even though they provide very limited evidence of its safety for children. The $2011 \mathrm{New}$ York Report sums up its key findings, starting with family engagement and satisfaction and ending with the early evidence that AR cases have similar re-report rates as TR cases. Based on this, together with a prediction that further follow-up will demonstrate a reduction in subsequent AR re-reports, it claims "positive evaluation results" and recommends that the legislature make DR permanent! ${ }^{210}$

205. Papers \& Reports, supra note 196 (listing 12 reports out of 42 listed, or $29 \%$, with Differential Response in the title).

206. GUTERMAN ET AL., supra note 7 at 58.

207. Id.

208. LOMAN \& SIEGEL, supra note 144 , at vi.

209. Id. at 1 .

210. RUPPEL ET AL., supra note 5, at v-vii, 103. 


\section{(b) Parent Satisfaction as Measure of Success}

When it comes to substance, the early advocacy research fails to pass the laugh test. At least it fails if you think that child interests should count as central. Each report places enormous emphasis on AR's success in pleasing parents-or what the authors call "families"-without specifying that their definition of families excludes children. Loman and Siegel, themselves, sum up their work, saying "The most consistent finding in our work is that, on average, families react more positively to . . . [AR] than to forensic investigations." ${ }^{11}$ Their Minnesota report's opening highlights summarize: "Most families liked the AR approach and responded more positively to workers who used it." ${ }^{212}$

Notably, although children in DR programs range widely in age and include a large proportion fully capable of voicing informative opinions,${ }^{213}$ no effort is made in the advocacy research to solicit their views.

The sections in this research proclaiming parent satisfaction are based on surveys of parents on the AR, as compared to the TR, tracks. Elaborate statistical charts demonstrate that parents on the AR track tend to like their treatment by CPS workers better than parents on the TR track. Parents on the AR track are, by definition, treated only in a parent-friendly way. They are offered services featuring financial subsidies like rent payments and household purchases. They are not investigated to see how they might have mistreated their children. They are not required to do anything. They are not told that the state can intervene to protect their children if they do not take the steps needed to become fit parents. Indeed they are told that they can walk away at any time without consequence. By contrast parents on the TR track can be required to engage in substance abuse and other rehabilitative treatment. They know that if they refuse to cooperate with such demands or if they continue to abuse and neglect their children, they risk having the children removed. What is not to like from the point of view of most parents diverted to the AR track? How can the IAR authors report this finding as if it is enormously significant, as if it constitutes important proof of success?

And yet, sophisticated DR movement strategists have poured millions of dollars into this research in a deadly-serious effort to radically change our nation's child welfare policy. They have appar-

211. L. Anthony Loman \& Gary L. Siegel, Hughes et al.: Science or Promotion?, 23 RES. ON SOC. WORK PRAC. 554, 556 (2013) (emphasis added).

212. LOMAN \& SIEGEL, supra note 144 , at vi.

213. MERKEL-Holguin ET AL., supra note 2, at 60 (providing that the mean age of children in three states' DR systems studied ranged from 5.4 years to 6.4 years). 
ently learned a scary lesson from the prior history discussed above..$^{214}$ Research findings that seem laughable can have a very significant effect on policymakers.

\section{(c) Parent Engagement Claims}

The early advocacy research claims that parents are actually engaged on the AR track more actively than parents on the TR track and thus that they receive more in the way of services that might reduce stress and help them avoid repeat maltreatment. ${ }^{215}$ There are a host of problems with this finding.

First, while the research refuses to discuss the dropout problem, it is clear that both the parent and worker surveys used to measure parent engagement are based on a highly selective, and by no means representative, sample of the whole AR group. The surveys are sent to only those parents who choose to engage in and complete the voluntary AR track program, and out of that group, only a small percentage responds to the survey. ${ }^{216}$ These parents are almost certainly those most invested in, and appreciative of, the program. By contrast, parent engagement for the TR group is measured for all parents on the track, including those who would much rather not be there. There is therefore no comparability between the two groups and no evidence as to the level of engagement of the entire group diverted to $A R$ as compared to the group kept on the TR track. However, we know that somewhere in the vicinity of one-third to two-thirds of those in the AR group are not, in fact, engaged since they dropped out. ${ }^{217}$

Second, the services provided on the AR, as compared to the TR, track are significantly different. AR track services are primarily financial benefits such as food or clothing, rent and utilities payments, and purchases of appliances and other household items, rather than the kinds of rehabilitative services designed to help unfit parents become fit like substance abuse treatment, anger management, and other parental fitness counseling. TR track services involve disproportionately more in the way of such rehabilitative services. ${ }^{218}$ Even if the DR research were capable of proving that parents were more engaged in AR services, this would say nothing about whether they were getting more in the way of services that were actually helpful in reducing child maltreatment.

\footnotetext{
214. See supra Part I.

215. See LOMAN \& SiEgEL, supra note 144, at x, 117; RUPPEL ET AL., supra note 5, at v-vi.

216. E.g., LOMAN \& SIEGEL, supra note 144, at 46; MERKEL-HOLGUIN ET AL., supra note 2 , at 49 .

217. See supra Part III.B.1.b.ii, infra Part IV.B.4.a.ii (discussing dropout rates in both Parts)

218. LOMAN \& SIEGEL, supra note 144 , at 52-57 figs.5.1 \& 5.2.
} 
Third, much of the research compares AR programs that have been given new funding for services and staff to TR programs that have received no new funding. ${ }^{219}$ A related issue characterizing virtually all of the research reports is that the social workers on the AR track have been given special training and directions not provided to the TR track workers. ${ }^{220}$

A comparison between tracks with different levels of funding and different types of training for staff and services proves absolutely nothing about whether a voluntary track would work better than a potentially coercive track in engaging parents and preventing maltreatment.

\section{(d) Child Safety Claims}

The early advocacy research claims that child safety is served as well or better on the AR track as on the TR track, generally relying primarily on comparative rates of re-reporting of child maltreatment. The research says that for AR families, these rates are roughly the same as, and in some cases lower than, the rates for CPS families. ${ }^{221}$

There are many problems with these safety claims. Most important is that there is no real focus on assessing the obvious risks of DR by social scientists free from bias, ${ }^{222}$ so there is no way to tell what might have surfaced if there had been such a focus.

In addition, many flaws in the safety claims are obvious. First, the reports imply, but do not actually make clear, that re-report rates for dropouts are included in the total rates for the AR group. Obviously, if they are not, then the re-report comparisons are close to meaningless, since as discussed above, the dropouts are likely the highest-risk group for repeat maltreatment. ${ }^{223}$

219. So, for example, in the early, influential Minnesota study, new foundation funds for services were made available to families on the AR but not the TR track. Id. at 19,66. The 2010 Ohio study reports that $\$ 1000$ per family was provided on the AR, but not the TR, track, crediting Casey Family Programs together with the Ohio Child Welfare Department for the new funding. LOMAN ET AL., supra note 132, at 15. The 2011 New York DR research report notes that extra funds were provided to families on the AR track. RUPPEL ET AL., supra note 5, at 17; see also Hughes et al., supra note 6, at 510-13 (reviewing the reports from Minnesota, Ohio, Nevada, and New York in Appendix A). The Final QIC-DR Report notes that in the later Ohio study, extra funds were provided to the AR track by both Casey and the QIC-DR grant. MERKEL-HOLGUIN ET AL., supra note 2, at 83 . Casey's DR Implementation Kit notes that "flexible funds" are generally provided to AR tracks and are essential to the system. GUTERMAN ET AL., supra note 7, at 49, 50.

220. See, e.g., RUPPEL ET AL., supra note 5, at iv (discussing the training provided to AR track social workers).

221. See, e.g., Puckett, supra note 1 (claiming slightly reduced re-report rates in AR families).

222. See discussion supra Part IV., including IV.A., B.1.a.

223. Tony Loman stated that his research did include the dropout re-report rates. Telephone Interview with Tony Loman, supra note 139. 
Second, even if dropouts were included in AR re-report totals, there is no reason to think that re-report rates reflect actual maltreatment rates for the dropout group in the same way that they reflect such rates for the AR participant group or the TR group, and there is no discussion of this issue. There is good reason to think they do not. There is a well-known and oft-discussed "surveillance bias" phenomenon. ${ }^{224}$ Families visited on a regular basis by social workers are more likely to be reported because these workers are mandated reporters. ${ }^{225}$ Families receiving services are more likely to be connected with community resources with their own mandated reporters. ${ }^{226}$ Families on the AR track who refuse services from the get-go will be free from this kind of surveillance, and families who drop out along the way will be relatively free.

Third, there is also no reason to think that re-reports accurately capture any differences in actual maltreatment between those who receive services on the $\mathrm{AR}$ track and those on the TR track, and there is no discussion of this issue. Again, there is good reason to think they do not. The point of the AR track is to be parent-friendly and not engage in the type of monitoring and surveillance designed to identify maltreatment that is more characteristic of the TR track. The workers on the two tracks are differently trained and socialized, and they operate from different perspectives about their roles. Accordingly, AR workers seem less likely to report for maltreatment parents with whom they engage than TR workers are to report parents engaging in similar maltreatment.

Fourth, the absence of any fact-finding investigation on the AR track, any findings about prior abuse and neglect, and any listing on maltreatment perpetrator registries will likely reduce the rate at which actual maltreatment is identified in the entire group diverted to AR, both dropouts and participants. Maltreatment findings are an important part of what social workers rely on in deciding whether to conclude that additional maltreatment has occurred and whether to report. Children on the AR track are less likely to be re-reported for maltreatment, as compared with children on the TR track, since their cases will be missing the information about prior incidents that would exist for similar cases on the TR track.

In addition to the suspect reliance on re-report rates, the research relies on social worker perceptions of family safety as an important measure of actual safety in comparing $\mathrm{AR}$ families to TR families. ${ }^{227}$

224. Conley \& Berrick, supra note 101, at 289.

225. Id.

226. Id. at 286 .

227. LOMAN \& SIEGEL, supra note 144, at 105-14; LOMAN ET AL., supra note 132, at 13033, figs. $11.2 \& 11.3$. 
There are many obvious problems with this measure. Among these are first, the likely bias of the workers who self-select for the AR track and are trained in ways designed to make sure they are true believers. Second, the worker assessments are based on the parents who have volunteered to participate to the end of the services period, at which point the only families left will be those that are most enthusiastic about the program and likely to be the lowest-risk families in the $\mathrm{AR}$ pool.

Finally, the research almost entirely ignores the huge safety risk posed to children as evidenced by the very high re-report rates characterizing both the $\mathrm{AR}$ and $\mathrm{TR}$ tracks. It mentions these rates, at best, only in passing, so that the normal reader would not even notice. But the problematic facts appear incidentally in at least some of the reports. As discussed above in section III.B.1.a.iii, re-report rates for AR families range from one-third to two-thirds, depending on the length of the follow-up period. For example, the 2004 Minnesota Report says the overall re-report rate is about one in three families during a relatively short tracking period of two to three years. ${ }^{228}$ It predicts that long-term rates would rise to something like the general CPS recurrence rate of $65 \% .{ }^{229}$ So claims of DR's success are based on a prediction that children on the AR track will be likely to be rereported for maltreatment at something at least close to a two-thirds rate! We have to assume that actual safety risks are even higher than these re-report rates suggest, since re-reports significantly underestimate maltreatment. ${ }^{230}$

The overall high re-report rate deserves center stage in any report truly focused on child safety and well-being. The overwhelming majority of children kept at home, whether on the AR or TR track, suffer repeated abuse and neglect. This is no surprise given that we have known for years that children once victimized by maltreatment are highly likely to be re-victimized. ${ }^{231}$ But it calls out for comparing how children might do in a CPS reform program that moves in the opposite direction from DR, providing more rather than less in the way of

228. LOMAN \& SIEGEL, supra note 144, at 141-42.

229. Id. A recent Loman and Siegel Ohio study reveals that nearly half of the families in the combined group of $\mathrm{AR}$ and TR cases had one or more screened-in re-reports. Loman \& Siegel, supra note 60, at 93.

230. See, e.g., IOM/NRC 2014 REPORT, supra note 2, at 205-06 (noting the critical need for studies that do not rely on re-report rates in assessing child safety); see KoHL, supra note 29 , at 3 (stating that recurrent maltreatment is underreported based on comparisons with self-reports); KOHL, supra note 29, at 5, 6, 8, 31 (noting very significant underreporting of maltreatment, including severely violent and neglectful parent ing, citing her own study and previous research); Kyte et al., supra note 50, at 126, 131; discussion infra Part IV.B.2.

231. See discussion supra Part III.A. 
intervention, more monitoring, more rehabilitative treatment, and readier removal in response to serious abuse and neglect.

\section{(e) Cost-Savings Claims}

The early advocacy research reports typically end with sections assessing DR costs and benefits. ${ }^{232}$ Again, the focus is one which largely ignores child interests. It also ignores long-term costs to the state.

The reports indicate that in the early years of DR programs the costs of the AR track are often greater than those of the TR track. But they claim that the DR system will be likely to reduce financial costs in later years. This claim is based almost entirely on anticipated reductions in removal to foster care associated with DR and, to a lesser degree, on reductions in other traditional CPS activities like investigations. ${ }^{233}$

But the reports simply assume that eliminating investigations and reducing foster care are good things, with no analysis whatsoever of whether it serves or disserves child interests. As discussed above ${ }^{234}$ good social science provides reason to think that, as a general matter, reducing the rate of removal to foster care will be harmful to children, putting them at greater risk for additional maltreatment and related problems. And to the extent that DR increases these longterm risks to children, it will prove enormously costly to society in financial terms. ${ }^{235}$

\section{The Independent Research}

Relatively few studies out of the entire body of DR research can be characterized as independent from the DR movement and free from the advocacy spirit animating the research described above. But all of these independent research studies have a very different character and message from the advocacy research.

Amy Conley's and Jill Duerr Berrick's 2010 California DR Report $^{236}$ is filled with important cautions. They note that taking together all of the DR research done to date, the findings are "equivocal" 237 by contrast to the success story claimed in the advocacy research. They point out that while DR systems are supposed to divert only low-risk cases to the AR track, they in fact regularly divert many "high-risk" and "very-high-risk" cases, ${ }^{238}$ with almost half of the

232. See, e.g., LOMAN \& SIEGEL, supra note 144, at 158-66.

233. LOMAN ET AL., supra note 132 , at 154 .

234. See discussion supra Part III.A.

235. See discussion infra Part V.B; see also infra text accompanying note 350.

236. Conley \& Berrick, supra note 101.

237. Id. at 283 .

238. Id. at $283,289$. 
cases in their own studies falling in these categories. They note that many DR approaches gaining support across the country "offer little more than referrals to community resources." 239 They flag the dropout issue, noting that "more than half of the families who were offered... [AR] services did not opt to participate in the program." ${ }^{240}$ They point out that this dropout problem limits the relevance of comparisons between AR and TR groups. ${ }^{241}$ And they note the high rereport rate characterizing both $\mathrm{AR}$ and $\mathrm{TR}$ track families-roughly one-third-with re-reports occurring sooner in the AR group. ${ }^{242}$

Conley and Berrick conclude with a stunningly different overall assessment of DR's "success" from that of the advocacy research. They find that while DR may provide families needed support, there is no reason to think it is useful in reducing child maltreatment. ${ }^{243}$

Some recent state research reports question the success of their own states' DR programs. The Wyoming Legislative Service Office includes in its 2008 report's "principal findings" that DR is "not effective in reducing families' severity of contacts" and that families on the voluntary track "rarely accepted services and their problems often worsened." 244 It recommends that CPS "evaluate how to make the track system effective or seek its repeal." ${ }^{245}$ It finds that the traditional CPS response is more successful than the AR approach in improving child welfare. ${ }^{246}$ It concludes that the AR system "is not improving families' lots, and worse, that it may very well leave children in chronic low-level maltreatment situations until their predicaments worsen to the investigation level." ${ }^{447}$

The Virginia Department of Social Service's 2008 evaluation of DR, conducted with the assistance of Virginia Tech, finds serious problems. ${ }^{248}$ It notes that the majority of AR cases- $54 \%$ - are high or moderate risk. ${ }^{249}$ It finds that AR families are less likely to accept services than TR families. ${ }^{250}$

239. Id. at 290

240. Id. (emphasis added).

241. Id. at 289 (indicating that there is no way to know that those who continued in the program were similar to those who dropped out since "[c]lients who were more troubled may have been more likely to opt for treatment, or alternatively, clients who were better prepared to change their parenting may have chosen to participate" (emphasis added)).

242. Id. at 286.

243. Id. at 290

244. MGMT. Audit Comm., supra note 130; see also id. at 21-22.

245. Id. at Executive Summary.

246. Id. at 24-25.

247. Id. at 30 .

248. Evaluation of the Differential RESPONSE System, supra note 57.

249. Id. at 14 .

250. Id. at 24 . 
The highly respected Institute of Medicine and National Research Council (IOM/NRC) issued a Research Workshop Summary in 2012 designed to sum up important child maltreatment research as a preliminary step to revising the IOM's 1993 Maltreatment Research Report. ${ }^{251}$ It states that the DR research studies "have not been able to rule out the possibility that increased harm might occur." ${ }^{252}$ It cites important questions raised by its consultant Richard Barth, Dean of the School of Social Work at the University of Maryland, including: (1) whether the early research findings would be vindicated by "more rigorous evaluation designs," and (2) why so few cases were being switched from AR to TR tracks based on safety concerns. ${ }^{253}$

In 2014, the IOM/NRC Final Report was published..$^{254}$ The Report notes that the number of rigorous evaluations is low and that more rigorous evaluations are needed. ${ }^{255}$ (It specifies that just three randomized, controlled trials, and seven quasi-experimental studies, had been conducted. ${ }^{256}$ And it emphasizes: "Perhaps most critically, there is a need for studies that do not rely solely on administrative [rereport] data." ${ }^{257}$ It questions whether re-report rates on the AR track provide any meaningful measure of child safety:

Because this finding is based on administrative data rather than direct measures of safety . . . it must be interpreted carefully, because the differential response process could plausibly result in less involvement of any agency with the children, who could then be less likely to be rereported even though they were being reabused. ${ }^{258}$

Deborah Daro and Kenneth Dodge conducted a comprehensive review of DR programs in a 2009 publication, finding "few positive effects on the initiative's four core outcomes-child safety, parental capacity and access to support, child welfare agency and network efficiency, and community responsibility for child protection . . . ."259

\footnotetext{
251. Olson \& STROUD, supra note 3, at 1-4.

252. Id. at 86 .

253. Id. at 87 .

254. IOM/NRC 2014 REPORT, supra note 2, at 1.

255. Id. at 206 .

256. Id. at 204 .

257. Id. at 206

258. Id. at 205 .

259. Deborah Daro \& Kenneth A. Dodge, Creating Community Responsibility for Child Protection: Possibilities and Challenges, Future OF ChILD., Fall 2009, at 84, available at http://futureofchildren.org/futureofchildren/publications/docs/19_02-04.pdf, archived at http://perma.cc/MXD4-TR6Y (discussing DR programs going by the name "community partnership").
} 


\section{Hughes and Rycus Analysis of the Early Advocacy Research}

The 2013 Hughes and Rycus article makes an enormous contribution to the DR debate. ${ }^{260}$ It was written from within the child welfare research world by highly respected scholars who have held, and who continue to hold, high-level positions with important organizations in the area of child maltreatment research. Ronald Hughes and Judith Rycus, the lead authors, serve as executive director and program director, respectively, of the North American Resource Center for Child Welfare, Institute for Human Services (IHS/NARCCW). ${ }^{261}$ Hughes also served as the president of APSAC and serves as its ongoing president emeritus. ${ }^{262}$

The IHS/NARCCW initiated in early 2010 a comprehensive research and literature review to address the organization's developing concerns with DR implementation and evaluation, including concerns about child safety. This resulted in publication of the Hughes and Rycus co-authored article in 2013, ${ }^{263}$ which triggered immediate attention. The editor of Research on Social Work Practice devoted the entire September 2013 issue to this article, related reaction papers, and a response to those papers by Hughes and Rycus. ${ }^{264}$

The Hughes and Rycus analysis provides a devastating critique that includes the following key elements. First, it questions the methodology of the DR advocacy research on multiple grounds, including the fact that experimental $\mathrm{AR}$ and control TR samples were not comparable and concludes:

To claim or imply that an intervention being evaluated is responsible for observed outcomes without fully considering the potential role of . . . other variables can provide a distorted and exaggerated picture of the state of our knowledge about an intervention's effectiveness.

. . . It is concerning that in most of the studies we reviewed, the claims presented in the research reports frequently overreached what might have legitimately been concluded, considering their many methodological limitations. ${ }^{265}$

260. See generally Hughes et al., supra note 6.

261. Staff, N. AM. RES. CTR. FOR CHILD WELFARE, http://www.ihs-trainet.com/ about/staff.htm (last visited Feb. 12, 2015), archived at http://perma.cc/8YX4-3QPR.

262. Board of Directors, AM. PROF'L SOC'Y ON THE ABUSE OF CHILD., http://www.apsac.org/board-of-directors (last visited Feb. 12, 2015), archived at http://perma.cc/6D8P-VWAA.

263. Hughes et al., supra note 6, at 495.

264. See generally id. (indicating that this article was the feature of the special issue on Issues in DR)

265. Id. at 500 
Second, they challenge the centrally important safety claim made by DR advocates-that DR does not put children at risk. They findbased on an extensive analysis of the nature of DR and of the research-both reason for concern about safety and inadequate evidence alleviating that concern. ${ }^{266}$ They point to the many reasons why re-report rates and worker assessments of family safety provide inadequate measures of comparative child safety on the two tracks, summarizing: "[I]t is not possible to conclude that a DR model exists that can ensure that children's safety is not compromised in alternative tracks." 267

Third, the article condemns the research as promotion masked as science:

[W]e found unsupported, inflated, and unfounded promotional claims to be a significant problem in the differential response . . . research we reviewed. . . [ [M] any of the studies . . . failed to fully articulate and explain study limitations and often failed to propose alternative explanations for study findings, thus increasing the likelihood that readers would draw erroneous conclusions not supported by the data. Many claims in this body of literature about the benefits of DR exemplify marketing and promotional strategies rather than objective science.

- . .

This type of promotion has no place in outcome research. The scientific and ethical foundations of outcome research, its empirical and ethical legitimacy, and its practical utility are all undermined or discounted by promotional strategies other than the accurate, objective, and transparent demonstration of evidence. ${ }^{268}$

Several leading experts and organizations within the child welfare field provided important support for Hughes's and Rycus's conclusions. Viola Vaughan-Eden and Frank Vandervort, then president and president-elect, respectively, of the APSAC, ${ }^{269}$ describe the Hughes and Rycus article as perhaps "the most important article in the child welfare arena in the past 15 years." program with so little empirical support gained such favor . . . in this

266. Id. at 500-04.

267. Id. at 504 .

268. Id. app.B, at 516.

269. APSAC is "the leading national organization supporting professionals who serve children and families affected by child maltreatment and violence." APSAC's 22nd Annual Colloquium, AM. PROF'L SOC'Y ON THE ABUSE OF CHILD. 18 (2014), available at http://www.mipsac.org/wp-content/uploads/2013/10/2014-Colloquium-Brochure.pdf, archived at http://perma.cc/5Z2X-9DSU. Ms. Vaughan-Eden is also the current President of the National Organization of Forensic Social Work. Biography, Viola VAughan-EdEN, http://www.violavaughaneden.com/sub_biography.asp (last visited Feb. 12, 2015), archived at http://perma.cc/NJF5-NV6Q.

270. Vaughan-Eden \& Vandervort, supra note 39, at 550. 
era of evidence-based practice." ${ }^{271}$ Their own explanation is the "unholy alliance" between left and right political forces, ${ }^{272}$ noting that just such an alliance partnered to enact the first DR legislation in Missouri in 1994. ${ }^{273}$ They also point to the role played by "politically connected private foundations," warning how that "can distort research designs, findings, and assertions about the efficacy of programming in the field of child welfare." ${ }^{274}$ Finally, they call for a moratorium on the use of DR until it has been "rigorously and honestly studied," warning that failure to do so will put children at undue risk. ${ }^{275}$

Christopher Baird co-authored an article on behalf of the National Council on Crime and Delinquency and the Children's Research Center, both important organizations in the child welfare and related research fields. ${ }^{276}$ This article notes that Hughes and Rycus are "internationally known experts with extensive experience in policy and program development, much of which was designed to improve practice through family engagement techniques[]. . . [and who] have also championed the application of research findings and evidence-based programs to inform program development."277

They praise the Hughes and Rycus paper for its "compelling critique" and its courage in taking on such a popular program. ${ }^{278}$ They join in questioning the DR research methodology, noting that with AR track programs receiving extra resources not provided to the TR track, "it would be surprising" if AR parents and staff did not find AR more responsive to family needs. ${ }^{279}$ They support the concerns with the accuracy of DR safety claims and warn of the need to be cautious about "creating cultures of 'naïve practice' in which workers focus solely on family strengths and protective capacities." 280

\footnotetext{
271. $I d$.

272. Id. (quoting BARTHOLET, supra note 1, at 44); see discussion infra Part V.B.

273. Id. at 550-51.

274. Id. at 551 .

275. Id. at 552-53.

276. Christopher Baird et al., Response to the Hughes et al. Paper on Differential Response, 23 RES. ON SOC. WORK PRAC. 535, 535 (2013).

277. Id.

278. Id.

279. Id. at 536

280. Id. at 537-38.
} 


\section{The QIC-DR Research ${ }^{281}$}

The DR movement planned the QIC-DR stage as the culminating research platform for mounting the final push for their hoped-for federal finance reform. The QIC-DR reports were to serve as the ultimate demonstration of the success of DR, providing a basis for federal government action diverting funding from traditional CPS programs to DR. ${ }^{282}$ In 2008, the U.S. Children's Bureau provided a fiveyear, multimillion-dollar grant in $2008^{283}$ to the AHA and its partners, including the IAR. ${ }^{284}$

Three state programs were chosen for study in Illinois, Colorado, and Ohio. The final state research reports were published in late 2013 and early 2014, and the Final Cross-Site Report, designed to compare and summarize the evidence from the three state program studies, was published in July $2014 .^{285}$

The reports reveal troubling evidence of the danger that DR poses for children, which is discussed below. ${ }^{286}$ However, despite this evidence, the reports read like success stories yet again. Indeed, the claim is now made that DR is ready not simply for dramatic expansion across the nation for the low-risk cases for which it was supposedly designed. The reports argue that the case has been made for expansion to high-risk cases! This conclusion is, of course, consistent with the Casey Family Programs goal of eliminating foster care altogether.

Thus the Ohio Final Report concludes, based on no comprehensible reasoning, that AR "may be effective among somewhat higherrisk cases." 287 The Colorado Final Report similarly argues for considering expansion of DR to high-risk cases without any apparent basis

281. Quality Improvement Center on Differential Response, UNIV. OF COLO. DENVER, http://www.ucdenver.edu/academics/colleges/medicalschool/departments/pediatrics/subs/ca n/QIC-DR/Pages/QIC-DR.aspx (last visited Feb. 13, 2015), archived at http://perma.cc/ZAY5-X8VD.

282. Morrison \& Dzuba, supra note 201, at 18 n.12 (citing conversation with Brett Brown, former cross-site evaluator for the three-state DR evaluation worked during the summer of 2013 for Commissioner Samuels in the Administration of Children and Families).

283. The U.S. Children's Bureau was credited for funding in the acknowledgments of the QIC-DR Final Cross-Site Report. MERKEL-HolGUIN ET AL., supra note 2, at i.

284. Id. at 5,10 .

285. MERKEL-HOLGUIN ET AL., supra note 2, at ii.

286. See supra Parts IV.B.4.a.i and IV.B.4.a.ii.

287. Julie Murphy et al., Human Servis. Research Inst., Ohio SOAR Project: FINAL REPORT 133 (2013), available at http://www.hsri.org/files/uploads/ publications/OHIO_SOAR_Final_Report.pdf, archived at http://perma.cc/E2DE-7FS8. The Report relies simply on the slightly lower foster care placement rate for AR and admits that "this evaluation has not truly tested the effectiveness of AR with higher-risk populations." Id. at 133. 
in evidence. ${ }^{288}$ This is especially interesting in light of the fact that DR in Colorado was triggered by a series of high-profile child fatalities in $2007 .{ }^{289}$ Such fatalities might be thought indicative of the need for more intensive intervention by CPS to monitor and consider removal of children; however, they were used instead to justify the institution of DR for low-risk cases, which is now alleged to be appropriate for high-risk cases.

The Final QIC-DR Cross-Site Report makes clear the general absence of evidence in the three QIC-DR state studies that AR works particularly well in any respect, even in terms of pleasing parents. ${ }^{290}$ Nonetheless, the Report ends by making claims that the studies have implications for widespread changes in traditional systems in the DR direction. Thus, the report raises questions as to whether "jurisdictions wish to consider that all families who are referred to CPS would be eligible for AR[,]" 291 whether higher-risk cases should be included in AR, and whether CPS workers should have the discretion to reassign TR families to AR. ${ }^{292}$ It makes the connection with federal finance reform, noting that reducing foster care placements and using Title IV-E waivers may be the way to fund DR. ${ }^{293}$ And finally, the Report indicates that DR may lead the way to fundamental change of the entire CPS system, so that CPS itself becomes an agency largely devoted to linking even high-risk families on a voluntary basis to services, rather than identifying perpetrators who can be required to engage in rehabilitation programs and whose parental rights can be restricted. ${ }^{294}$

This movement to expand DR to virtually all CPS cases, including high-risk cases, is inconsistent with the reasoning on which DR was originally premised. And even some of DR's most important supporters, Tony Loman and Gary Siegel, stated in a recent article that AR is inappropriate for high-risk cases, arguing based on their research that it should be targeted toward families without prior maltreatment reports rather than toward chronic offenders or parents with "deeper and more intractable problems, such as mental illness, substance abuse, domestic violence or children that are difficult to care for, which often characterize families frequently encountered by CPS." ${ }^{295}$

288. WINOKUR ET AL., supra note 56, at 124 ("[T] he question must also be asked about whether the Colorado DR model could benefit high-risk families as well."); see also id. at 124-25 (stating the Report's final conclusions).

289. Id. at ix.

290. MERKEL-HOLGUIN ET AL., supra note 2, at 68-129.

291. Id. at 122

292. Id. at 124

293. Id. at 125

294. Id. at 127-28.

295. Loman \& Siegel, supra note 135, at 1666. 


\section{(a) New Evidence of Safety Risks in Differential Response}

The QIC-DR research provides powerful evidence of the risks that DR poses to children, however minimized those risks are by the authors. This evidence appears in connection with the Illinois DR program, which is interesting because Illinois diverted an unusually low percentage of cases to the AR track, ${ }^{296}$ presumably a much lower-risk group overall than the groups that are more typically diverted to AR.

\section{i. High Re-Report Rates on the Voluntary Track}

DR advocates have made the claim from the beginning that DR poses no additional risks to children, citing as primary evidence that re-report rates for families on the $\mathrm{AR}$ track were the same as, or lower than, rates for families on the TR track. But the Illinois QIC-DR research finds higher re-report rates for the AR track. ${ }^{297}$ Moreover, the difference in re-report risk increased over time, ${ }^{298}$ making it likely that the difference would be even greater a year or two out.

This is dramatic new news. One investigative journalist sums up the significance as follows:

The long delayed release of an evaluation of Illinois' differential response program casts new doubts on whether one of the country's most popular child welfare reforms is safe for children and a smart way to spend limited resources dedicated to families on the fringe.

According to the report, children whose parents had benefitted from twice as much social work time, $\$ 400$ stipends and a philosophy that stresses family strengths were more likely to be reported for child maltreatment and become victims of substantiated abuse or neglect.

This controverts 20 years of evaluations and assurances that children involved with ... [DR] programs across the country were as safe or safer than children who received traditional child protective services. ${ }^{299}$

In addition, all three state that the QIC-DR studies found very high maltreatment re-report rates on both the AR and TR tracks, a fact that prior DR research revealed only in passing, if at all. The Ohio Final QIC-DR research reveals re-report rates of $37 \%$ for AR families and 36\% for TR families. ${ }^{300}$ The Colorado Final QIC-DR re-

296. See MERKEL-HolgUIN ET AL., supra note 2, at 28-29.

297. FULlER ET AL., FINAL QIC-DR IL REPORT, supra note 2, at 65 (providing that $18.8 \%$ of the AR families experienced re-reports, as compared to $14.7 \%$ of the TR families, within 18 months of case closure).

298. Id. at 65-66.

299. Heimpel, supra note 7.

300. MURPHY ET AL., supra note 287, at 113. 
search reveals re-report rates of $44 \%$ for $\mathrm{AR}$ families and $45 \%$ for TR families within a short year of the initial referral to CPS. ${ }^{301}$

\section{ii. High Drop-Out Rates and Related Safety Risks on the Voluntary Track}

The Illinois Final QIC-DR research finally provides evidence about the AR dropout population. ${ }^{302}$ The revelation of this information seems motivated by the authors' need to explain away the disturbing finding that AR re-report rates are higher than TR rates. ${ }^{303}$ One has to ask whether, had the authors of the earlier advocacy research been willing to provide the dropout breakdown statistics, we would have seen similarly disturbing evidence. In any event, the Illinois dropout statistics provide stunning new evidence of the risks inherent in DR.

First, of those originally allocated to the AR track, almost one in three drop out. Less than half of those originally diverted to AR complete the program. (The additional one-sixth is transferred to DR, because their cases are re-assessed as high risk.) Those withdrawing after first starting down the AR track have the highest re-report rates of all. Those on the TR track have the lowest re-report rates of all. For substantiated re-reports, the findings are similar, with AR withdrawers having the highest re-report rates and the TR rates coming in close to the bottom of the various $A R$ and $T R$ groups. ${ }^{304}$

These data on dropout re-report rates-the first provided over many years of this advocacy research-are stunningly negative for DR proponents. The fact that those who participate and then drop off the $A R$ track have the highest re-report rates of all groups raises powerful questions about the success of DR programs in assessing risk for purposes of assigning children to AR, the success of $A R$ services in addressing maltreatment problems, and the risks for children of being on the AR track.

The fact that the overall dropout rate is close to one-third, counting those refusing services from the outset, is similarly troubling. DR is justified in large part as a way of providing services that allegedly are not being provided on the traditional CPS track. In Illinois, DR was supposed to respond in part to the fact that the state was not meeting federal requirements for providing services to children identified as victims of child maltreatment. ${ }^{305}$ But now we know that the

301. WINOKUR ET AL., supra note 56, at 59.

302. FULLER ET AL., FINAL QIC-DR IL REPORT, supra note 2, at 68-69.

303. See id. at 66 .

304. For the data in this paragraph, see $i d$. at 68-69.

305. Id. at 14-15. 
AR track also fails to provide services to a substantial proportion of all of its families.

The fact that less than half of the original AR track families end up completing AR services also calls into question all aspects of the DR research over the years based on parent and worker surveys, since these surveys are based on only a small sample of those who complete AR services. ${ }^{306}$

A final, supremely interesting fact revealed by the breakdown is that parents refusing $A R$ services from the get-go have next to the lowest re-report rates and the lowest substantiated re-report rates. ${ }^{307}$ This puzzling fact is left totally unexplored by the Illinois Report. Interestingly, the authors make no claim that this represents the actual maltreatment rate for this population. Indeed, it would be problematic for DR proponents to assert that the families who do best of all are those left totally free from the supposed benefits of AR services.

But it is important to ask why these re-report rates for the early dropouts are so low, now that we finally have this breakdown. It seems likely that this low re-report rate is simply not an accurate reflection of the actual repeat maltreatment rate-that maltreatment that occurs among families who refuse ever to participate in AR is not being captured by official reports in the same way it is captured for other AR and TR families. As discussed above, this group is free from the kind of surveillance characterizing participants on both AR and TR tracks, surveillance that is more likely to trigger reports. ${ }^{308}$

If the low re-report rate for early dropouts has no real relationship to actual maltreatment rates, then all of the DR claims regarding child safety based on re-report rates made over the years are questionable.

\section{(b) Continuation of the Advocacy Research Mode}

The QIC-DR research program promised to "rigorously study implementation, outcomes, and cost impact of DR." ${ }^{09}$ Given the powerful attack by Hughes and Rycus on the earlier advocacy research and the explosive debate reflected in the Research on Social Work Practice special issue, one might have hoped that those in charge of the QIC-DR program would have consulted broadly to come up with a new research team, a new set of research questions, and a new re-

306. Only a small percentage of those completing services and receiving survey questions actually respond to the surveys. See, e.g., WINOKUR ET AL., supra note 56, at 15 (noting a $21 \%$ response rate); discussion supra Part IV.B.1.c.

307. For the data, see FULlER ET AL., FINAL QIC-DR IL REPORT, supra note 2, at 66-67 fig.29, 71 fig.31.

308. See supra Part IV.B.1.d.

309. BROWN ET AL., supra note 67, at 5. 
search design. Instead, the research leadership team involves the same people and organizations central in the early advocacy research and, not surprisingly, has largely replicated that research approach. Only one of the three Final Reports even refers to the Hughes and Rycus article. ${ }^{310}$ The Final Cross-Site Report makes no mention of it.

This QIC-DR leadership team is responsible both for promoting and developing the DR model across the United States and for the research that is supposed to assess the value of that model. ${ }^{311}$ This represents the same troublesome merger of advocacy and research roles that has plagued DR from the beginning.

Loman and Siegel, along with the IAR, are credited in the QIC-DR reports as consultants and for contributing their research design. ${ }^{312}$ While they did not actually author the reports, their influence in the design and implementation of the research is apparent. The QIC-DR reports largely track the topics and organization of the earlier IAR reports and reflect a similar methodology. Casey Family Foundation staff members are acknowledged as advisors. ${ }^{313}$

Most of the troubling features of the earlier research are replicated. So, for example, new funding is provided for services on the AR, but not the TR, track; ${ }^{314}$ and AR staff are specially selected and trained. ${ }^{315}$ Comparisons are then made between $\mathrm{AR}$ and TR tracks, and claims

310. WINOKUR ET AL., supra note 56 , at 1-2, nn.7-8. The only significant concession to the critique of the earlier advocacy research is the decision to pursue an intent to treat methodology, including in the AR sample for analysis the cases switched from the AR to the TR track. The IAR removal of these switched cases from the AR analysis had been criticized by Hughes and Rycus in their response article in the Social Work Practice special issue. Ronald C. Hughes \& Judith S. Rycus, Discussion of Issues in Differential Response, 23 Res. ON SOC. WORK PRAC. 563, 574 (2013).

311. MERKEL-HOLGUIN ET AL., supra note 2, at 5, 10.

312. FULLER ET AL., FINAL QIC-DR IL REPORT, supra note 2, at ii (providing that Loman, Siegel, and the IAR contributed "countless hours of consultation and wisdom ... and ... detailed comments on earlier versions of this report"); WINOKUR ET AL., supra note 56, at iii (listing Loman and Siegel on the acknowledgements page and thanking them for research design that informed the Colorado evaluation); see also MURPHY ET AL., supra note 287, at Acknowledgements (thanking the QIC cross-site team at the Kempe Center and Walter R. McDonald and Associates). The Final QIC-DR Cross-Site Report says IAR "served in an advisory capacity throughout the project, especially around the evaluation and instrument design[]" and notes that the evaluation instruments developed by Loman and Siegel were most commonly used. MERKEL-HOLGUIN ET AL., supra note 2, at 10,50 .

313. MERKEL-HolgUIN ET AL., supra note 2, at i (listing them as members of the QICDR's National Advisory Committee on the acknowledgements page).

314. See, e.g., BROWN ET AL., supra note 67, at 23 (noting that all three sites have dedicated funds for AR cases available for "quick and concrete support services . . . . [and that] IR workers in both Ohio and Illinois expressed some frustration with the unequal access to funds for the families they serve"); see also MURPHY ET AL., supra note 287, at 83 (discussing funds from QIC-DR grant and Casey Family Programs).

315. BRown ET AL., supra note 67, at 25-30; see MURPHY ET AL., supra note 287, at 3954,132 . 
for AR success are made, with limited acknowledgement that any such success might be due simply to the differences in funding and staffing. Indeed, in Illinois, an increased caseload size for the TR workers based on the DR program was reported. ${ }^{316}$ And in all three states, workers reported workload inequities, ${ }^{317}$ with TR track workers in Illinois saying that they were limited in their ability to provide services by high caseloads and time limitations. ${ }^{318}$

There is the same troubling difference in types of services provided, with a greater emphasis on the AR track on financial support and a greater emphasis on the TR track on rehabilitative treatment. ${ }^{319} \mathrm{In}$ the Illinois system, for example, cash assistance of up to $\$ 400$ was available to $\mathrm{AR}$ parents, ${ }^{320}$ in addition to other supportive services including: "car repair or transportation; housing assistance; food or clothing; appliances, furniture, or home repairs; help paying utilities; welfare/public assistance services; medical or dental care; other financial help; . . cooking [and] cleaning . . .." ${ }^{321}$ The Illinois Report characterizes AR services as "especially poverty-related." ${ }^{22}$ TR services were more likely to include counseling, domestic violence services, parenting skills and related training, substance abuse treatment, and help getting mental health services. ${ }^{323}$ As with earlier DR advocacy research, there is no adequate discussion of how these differences in services make comparisons between success on the different tracks questionable and no discussion at all of whether shifting the emphasis so significantly from rehabilitative to financial support services is helpful in protecting children.

There is the same use of cost savings as supposed evidence of success when it is, of course, predictable that eliminating investigations and reducing the use of foster care would reduce costs. ${ }^{324}$ There is the

316. BROWN ET AL., supra note 67, at 30. The Illinois Report is guilty of an outrageous additional apples and oranges comparison that proves nothing regarding the alleged differences in the level of services provided on the two tracks. The Report first claims that the AR track provides more services than the TR track, only to later admit that the comparison is based on a period of time when the AR workers are supposed to be providing services but when the TR workers are supposed to be simply investigating, with the TR system designed to provide services at a later stage of the TR process. FULLER ET AL., FINAL QIC-DR IL REPORT, supra note 2, at 61, 82 n.30.

317. BROWN ET AL., supra note 67, at 35 .

318. FULLER ET AL., FINAL QIC-DR IL REPORT, supra note 2, at 59.

319. See MERKEL-Holguin ET AL., supra note 2, at 7, 85 tbl.7.2, 119.

320. FULLER ET AL., FINAL QIC-DR IL REPORT, supra note 2, at 2.

321. Id. at 4, 53; see also MURPHY ET AL., supra note 287, at 85 tbl.4.7, n.52 (providing a similar list of AR services).

322. FUller et AL., FInAL QIC-DR IL REPORT, supra note 2, at 10.

323. Id. at 53-56 tbl.5, figs. 20 \& 21; MERKEL-HolgUIN ET AL., supra note 2, at 7; MURPHY ET AL., supra note 287, at 83 tbl.4.6; WINOKUR ET AL., supra note 56, at 79.

324. FULLER ET AL., FINAL QIC-DR IL REPORT, supra note 2, at 85 (noting cost savings due to investigations and child removals on TR track); MERKEL-HOLGUIN ET AL., supra note 
same failure to seriously engage with whether such financial savings come at the cost of increased maltreatment of children.

There is the same advocacy tone. For example, the Ohio QIC-DR Final Report's introductory chapter ends with this statement of what is to come: "[W]e describe in more detail how AR is perceived as effective in terms of implementation, practice, and outcomes." 325

There is the same glossing over of problematic issues indicating risks for children and the same rosy "read" of the evidence to produce an enthusiastic success story. As discussed above, ${ }^{326}$ the Illinois QICDR Report reveals disturbing new evidence that DR poses risks to children, showing that parents on the AR track have higher re-report rates than TR track children, that $\mathrm{AR}$ track parents drop out at extremely high rates, and that AR parents who drop out have the highest re-report rates of all groups assessed. However, the Illinois Report's concluding chapter portrays DR as a shining success:

One of the most consistent findings to emerge from the Illinois DR evaluation is that parents who received DR felt more strongly positive about all aspects of their child protective services experience when compared to parents who received an investigation.... [A] significantly greater percentage of parents who received DR had more positive emotional responses and fewer negative ones, were more highly engaged, and were more highly satisfied with their worker and the services they received. ${ }^{327}$

It sums up safety issues, stating that "[t]he totality of all available evidence from ... [the] six rigorous [randomized controlled trial studies to date] seems to indicate that children who receive DR are at least as safe as those who receive an investigation." 328 This statement conveniently avoids reference to the Illinois Report's own devastating conclusions regarding child safety in the Illinois DR program. ${ }^{329}$ In an interview, the lead researcher for this Illinois study confessed that while their research found that " families like it better . . . [and that

2, at 8, 106; MURPHY ET AL., supra note 287, at 125 (containing a small sample that indicated limited cost savings with the DR program, which was primarily attributable to foster care reduction).

325. MURPHY ET AL., supra note 287, at 12.

326. See discussion supra Part IV.B.4.a.

327. FUlLer eT AL., FINAL QIC-DR IL REPORT, supra note 2, at 91.

328. Id. at 92 .

329. See supra Part IV.B.4.a. See also WINOKUR ET AL., supra note 56, at 71-75, 110 (massaging the Colorado QIC-DR report evidence to find positive safety implications). The Report claims that the "lack of a statistically significant finding for the short-term safety outcomes was not surprising given that the DR system reform also enhanced traditional CPS practices" with scant evidence of the latter. WINOKUR ET AL., supra note 56, at 110 . It claims that "[t]he most promising finding was that there may be long-term child safety benefits and cost savings due to lower levels of re-involvement, over time" for AR families. This is based solely on the iffy "survival analysis" which purports to predict, in the absence of referrals actually observed during the study period, what future referrals will take place. Id. 
i]n that sense it works fine. If you look at safety you may have a different answer." "330 Nonetheless, she concluded that DR was "a promising practice." ${ }^{331}$

The Final Cross-Site QIC-DR Report notes that Illinois broke down the groups on the AR track for the first time, but then fails to provide any information whatsoever about the troubling evidence of safety issues that the breakdown revealed, including the evidence that AR dropouts had the highest re-report rates of all groups. ${ }^{332} \mathrm{In}$ stead, the Cross-Site Report simply refers the reader to an appendix that was unpublished and thus unavailable on the website at the time of the Report's online publication! !33 $^{33}$

There is the same troubling emphasis on parent satisfaction and parent perceptions of their own engagement as measures of success. ${ }^{334}$ But prior research problems are now topped by the use of parent views to make safety claims. Thus, parent perceptions of child safety and family well-being are used as key indicators of the allimportant child safety findings. ${ }^{335}$ All of the problems discussed above $^{336}$ plague this attempt to use parent views as proving anything other than the completely unsurprising conclusion that the relative handful of parents who choose to fill out the survey, among the already limited group sticking with the voluntary program to the end, are prepared to say they think it has helped them, and that they report feeling more positive about the program than parents on the TR track who, of course, may not like the fact that they are subject to investigations, monitoring, and the threat of further intervention based on repeated child maltreatment. Using these parent perceptions as evidence of child safety seems an obviously desperate move, triggered perhaps by the absence of other helpful evidence.

In addition, removal to foster care is now used as an important supposed measure of child safety. ${ }^{337}$ The fact that somewhat greater

330. Heimpel, supra note 7 (quoting Tamara Fuller, Director of the University of Illinois at Urbana-Champaign's Center on Child Welfare Research).

331. Id. (quoting Tamara Fuller, Director of the University of Illinois at UrbanaChampaign's Center on Child Welfare Research).

332. See supra Part IV.B.4.a.ii.

333. MERKEL-HolgUIN ET AL., supra note 2, at 53-54, 123-24.

334. See, e.g., MURPHY ET AL., supra note 287, at 132 ("[W]hile AR did not result in higher levels of family satisfaction, AR families did report being more likely to contact their worker in the future, being better off and better parents because of their experience with the agency, and report higher levels of engagement in the case work process.").

335. See, e.g., FUller ET AL., FinAl QIC-DR IL REPORT, supra note 2, at v (Table of Contents chapter 6, "Child Safety and Family Well-Being," listing the following after "6.5 Child Removals:" "6.6 Parent Perceptions of Child Safety" and "6.7 Parent Perceptions of Family Well-Being"); WINOKUR ET AL., supra note 56, at vi, 76 (using parent perceptions to measure child safety and family well-being).

336. Supra Parts IV.B.1.b, IV.B.1.c.

337. MURPHY ET AL., supra note 287, at 115-16. 
use has been made of foster care to date on the TR track, with more also predicted for the future, is used to claim that children are less at risk on the AR track, with no discussion as to why this measure should count as a proxy for child safety. Given that the whole point of AR is to reduce the use of more intensive and intrusive methods of child protection, the reduced use of foster care is no surprise. Obviously, one could predict a reduction in such use. The big question that DR poses, though, is whether such reduction helps or hurts children. There are many reasons to think that foster care removal generally serves to protect children. ${ }^{338}$ This is part of why questions have been raised from the beginning as to whether DR puts children at undue risk. These DR reports simply ignore all of the obvious problems with using this as a measure of success and claim, case proven! ${ }^{339}$

\section{The Underlying Politics: Why the Resistance to Child- FRIENDLY CHILD WELFARE POLICIES?}

Why this DR Movement? Why has it gained such traction given all of the obvious risks to children and flaws in the research? Why this succession of extreme family preservation movements with similar characteristics? Understanding all of this is key to making the future of child welfare different.

The real reasons for these policies must be different from the reasons given. Those given are too obviously questionable, and the research cited in support of these policies is too obviously flawed. So, for example, with IFPS, it is hard to believe that those promoting these policies really thought child abuse was typically just a six-week crisis that could be solved with social worker support and house cleaning. With Racial Disproportionality, it is hard to believe that those promoting the racial bias theory really thought blacks could just overcome through their unique family strengths the poverty and related conditions that predicted child maltreatment for other groups. And now with DR, it is hard to believe that the proponents really think parents who suffer from substance abuse, mental illness, and other serious dysfunction characterizing those responsible for child maltreatment will magically become nurturing parents simply because parent-friendly social workers hand them rent payments.

338. See discussion supra Part III.A.

339. When asked about this problem in the research, Tony Loman said that no research studies were contemplated assessing whether the children kept at home pursuant to DR were, in fact, better or worse off than the children removed to foster care. Telephone Interview with Tony Loman, supra note 139. The 2013 QIC-DR Ohio Report does concede that higher removal rates might relate to a greater concern by TR investigators with child safety, but it argues that the DR research suggests that vigilance regarding safety is not relaxed under AR. They concede that the reasons for the differences in removal rates might be examined in research. MURPHY ET AL., supra note 287, at 48-49. 
Some would say that family preservation simply reflects deeply held values about family privacy in our society. ${ }^{340}$ We value individual autonomy in ways that few other nations do, and this is reflected in constitutional and other policies protecting the family against state intervention. ${ }^{341}$

But family privacy is not always sacrosanct. Women's rights advocates fought the idea of family privacy when they saw women victimized by domestic violence and felt the need for protective intervention by the state. ${ }^{342}$ They fought the idea that relationships in which women were victimized were the kinds of families that deserved preservation. ${ }^{343}$ And they have achieved dramatic changes in policy over recent decades, expanding state intervention with the goal of liberating women from families that do not function the way families should.

Why have children not been seen as entitled to similar liberation?

\section{A. Children Have No Rights}

Unlike women, children have no rights. This is true in the literal sense that they-especially the most vulnerable among themcannot speak for themselves, demonstrate on the streets, vote, get themselves elected to office or appointed as judges, and do the other things that adults do both in expressing their rights and in pushing for the establishment of additional rights.

As a formal legal matter, children have no rights to nurturing parents under federal or state constitutional law. By contrast, parents have powerful constitutional rights to hold onto and raise their children free from undue state intervention. This constitutional framework both reflects our societal values and helps to shape our entire CPS system. ${ }^{344}$ It makes extreme family preservation policies seem right and just.

The rest of the world thinks of children as having rights, at least as a formal matter. Virtually all other countries have ratified the Convention on the Rights of the Child (CRC), which accords children equal status with adults as rights holders. Under the CRC, children

340. Martin Guggenheim, Somebody's Children: Sustaining the Family's Place in Child Welfare Policy, 113 HARV. L. REV. 1716, 1741-42 (2000) (reviewing BARTHOLET, supra note 1).

341. Id.

342. BARTHOLET, supra note 1 , at 50-54.

343. Id.

344. For powerful challenges to this understanding of the traditional constitutional framing of child and parent rights, see James G. Dwyer, A Constitutional Birthright: The State, Parentage, and the Rights of Newborn Persons, 56 UCLA L. REV. 755 (2009) [hereinafter Dwyer, A Constitutional Birthright]; James G. Dwyer, The Child Protection Pretense: States' Continued Consignment of Newborn Babies to Unfit Parents, 93 MinN. L. REV. 407 (2008) [hereinafter Dwyer, The Child Protection Pretense]. 
have rights to nurturing parents and rights to be protected against abuse and neglect. Under the CRC, nations have duties to protect children against maltreatment and to ensure that children receive appropriate nurturing. ${ }^{345}$ These aspects of the CRC are part of the explanation for why the United States has not ratified the CRC. ${ }^{346}$

\section{B. The Left-Right Bargain: A Cheap Version of the War on Poverty ${ }^{347}$}

Many of those advocating for extreme family preservation policies appear to be using children to promote an anti-poverty agenda. The children at risk for abuse and neglect are disproportionately the children of the poor. Left-wing forces committed to helping poor people and historically oppressed racial minority groups often see efforts to intervene in families to protect children as yet another attack upon already victimized groups. They often see family preservation services as providing at least some financial and other support for poor families in a society reluctant to provide enough support.

Family preservation programs do, as a general matter, provide financial stipends and related forms of support for a subset of poor families. If children identified as at risk for abuse and neglect are kept at home, or returned home from foster care, the parents often receive supportive services. IFPS programs offered housekeeping, childcare, transportation and other services, and many other family preservation programs offer similar assistance. DR programs pride themselves on providing financial support.

Right-wing forces often see family preservation policies as a way to reduce government and save money. Those promoting family preservation provide evidence and arguments to support the costsaving goal. And short term, these policies often do save money. Eliminating CPS jurisdiction over families eliminates the costs of social worker monitoring. Reducing foster care eliminates the cost of foster parent stipends as well as CPS administration. Most family preservation policies, including both IFPS and DR, have been sold in significant part on the basis of such cost-savings arguments.

But there are problems with this left-right bargain that should trouble people on both sides of the political spectrum. For the left, this is a pathetically limited anti-poverty strategy. Providing poor people and oppressed racial minority groups the limited financial

345. Elizabeth Bartholet, Ratification by the United States of the Convention on the Rights of the Child: Pros and Cons from a Child's Rights Perspective, 633 ANNALS AM. ACAD. POL. \& SOC. SCI. 80, 85-86, 91-94 (2011).

346. Id. at 87-88, 91-94.

347. For discussion of the left-right politics of child welfare, see BARTHOLET, supra note 1, at 44-55, and also see GELLES, supra note 37, at 132-33. 
subsidies available in these family preservation programs is no road to empowerment.

Moreover, if the best we can do today are limited poverty alleviation efforts, it is wrong to choose one that comes at the expense of the most powerless subset of the poor-the children victimized by abuse and neglect. And it may ultimately be counter-productive: children so victimized are disproportionately likely to grow up impoverished themselves, and in the ranks of the homeless, the unemployed, and those addicted to drugs and alcohol. ${ }^{348}$ They are also disproportionately likely to victimize their own children, thus continuing the vicious cycle into future generations. ${ }^{349}$

It is also perverse to select that small subset of the poor who abuse and neglect their children as the beneficiaries of this limited anti-poverty campaign. Most poor people do their flat-out best to raise their children well, providing loving and nurturing care despite the oppressive conditions of their lives. Why should they be denied the financial benefits that abusive parents get in the form of family preservation services?

For the right, extreme family preservation policies may look cheap, but in the long run, they are very expensive. Children who are denied appropriate nurturing and who end up in disproportionate numbers on welfare, in prisons, and suffering emotional and physical disabilities are children who are very expensive in the long run. ${ }^{350}$

\section{Private Wealth Dominance over Policy Advocacy and Research}

For the past several decades, a small group of enormously wealthy and powerful organizations have dominated both policy and research in child welfare. From the 1980s through the 1990s, it was the Edna McConnell Foundation and the Annie E. Casey Foundation leading the charge on IFPS. ${ }^{351}$ More recently, it has been a combination of the Casey Foundations, primarily the Annie E. Casey and the Casey Family Programs Foundation, leading the charge on Racial Disproportionality and DR..$^{352}$

Research is desperately needed to guide policy. This is always true, given the difficulty of knowing how different policy ideas will play out in the real world. It is particularly true in child welfare giv-

\footnotetext{
348. BARTHOLET, supra note 1, at 95-97.

349. BARTHOLET, supra note 1 , at 96 .

350. See BARThOLET, supra note 1, at 55; Bartholet, supra note 26, at 1350 n.75.

351. See supra Part I.A.

352. See supra Introduction and Part I.B.
} 
en the danger that policies purporting to serve child interests will actually be motivated by various adult interests.

It is extremely dangerous to have one set of wealthy, private players dominating both policy advocacy and research to the degree that they have..$^{353}$

\section{FUTURE DIRECTIONS FOR REFORM}

\section{A. Children's Rights}

We need a radical upending of the rights hierarchy in this country, so that children are valued equally with adults and their most fundamental rights to grow up with nurturing parents are valued equally with adult rights to raise their children. ${ }^{354}$

Ratification by the United States of the CRC, or some other dramatic move to grant children equal status with adults as rights holders, would be a meaningful step forward in changing the dynamics of child welfare..$^{355}$

But it would not by itself solve the problem. Even with formal rights, the fact that children are inherently powerless as compared to adults will make a huge difference. Adults like to think that they love and appreciate children, but there is always a risk that those with more power will exploit and oppress those with less. And there is always a risk that adults claiming to represent children will be using children to promote various adult agendas. We need to acknowledge the challenge of granting children truly equal recognition in law and policy and begin to design new ways of holding accountable the adults who in the end will still make so many decisions about children.

\section{B. Maltreatment Prevention: Radical Social Reform, Early Supportive Intervention, and CPS Reform}

The DR proponents are right to say that maltreatment is rooted in poverty and social injustice. They are right to say that we should focus more on early prevention of maltreatment. But they propose a solution that utterly fails to meet the mark. Providing rent stipends and other financial benefits to the tiny subset of the poor who maltreat their children is no empowerment strategy, nor will it do much to prevent maltreatment.

353. See Bartholet, supra note 23, at 880-90.

354. See generally Dwyer, A Constitutional Birthright, supra note 344 (arguing that a child's constitutional rights should be a paramount consideration when deciding the child's parentage); Dwyer, The Child Protection Pretense, supra note 344 (arguing that children should be protected from birth from unfit parents).

355. See Bartholet, supra note 345, at 84-94, 99. 
We need a true war on poverty of the kind that President Lyndon Johnson announced ${ }^{356}$ but that no president since has renewed. We need serious programs to address poverty and the conditions associated with poverty, including unemployment, substance abuse, mental illness, and blighted neighborhoods.

Critics of the earlier family preservation movements that preceded this DR movement noted that they also constituted cheap and, in the end, utterly inadequate attempts to address the issues of poverty and injustice underlying child maltreatment. They noted that we needed a far more radical engagement with these issues, a true war on poverty. One of the authors of a landmark critique of IFPS, concluded in a later article that IFPS was doomed to failure because the problems producing child maltreatment were "rooted in poverty, unemployment, inadequate housing, substance abuse, and severe and persistent mental illness." ${ }^{57}$ My 2009 article on the Racial Disproportionality movement argued that it was similarly misdirected, proposing a false solution that avoided the real problems and the need for truly radical social reform. ${ }^{358}$

While such reform is sadly not on the immediate horizon, there are programs that could make a major difference that would not require radical social changes or overwhelming financial commitments. We should embrace these. So, for example, we should expand the programs that target parents at risk for maltreatment early on, before they fall into the kind of dysfunction that breeds maltreatment. This is the stage at which we have evidence that prevention efforts have the best chance of working. There are at least a number of early home visitation programs with powerful evidence of success in reducing maltreatment and reducing important predictors for maltreatment. ${ }^{359}$ We need to devote massively increased resources to these programs and to the development of other promising programs similarly targeted to early prevention.

We also need to do some version of DR but within the framework of the traditional CPS system. For this, we need new resources devoted to CPS, since a large part of the reason that it provides so little in the way of services to the families on its caseload has to do with the inadequacy of resources. Additional resources are also needed to

356. President Lyndon B. Johnson, State of the Union (Jan. 8, 1964).

357. Julia H. Littell, Effects of the Duration, Intensity, and Breadth of Family Preservation Services: A New Analysis of Data from the Illinois Family First Experiment, 19 CHILD. \& Youth SERVS. REV. 17, 36 (1997).

358. Bartholet, supra note 23, at 923; see also Bartholet, supra note 26, at 1341-42 n. 58 (quoting the papers summing up the evidence produced at the conference on Racial Disproportionality co-sponsored by Harvard Law School's Child Advocacy Program and Chapin Hall at the University of Chicago).

359. See BARTHOLET, supra note 1, at 165-68; Bartholet, supra note 26, at 1346-50. 
enable CPS to protect the children at highest risk through monitoring, mandated rehabilitative programs for parents, removal to foster care, and adoption.

Resources will be hard to come by. Part of the allure of all family preservation proposals is that they promise to save money. But we cannot protect children adequately on the cheap. And we are not really saving state funds by allowing children to be abused and neglected. Many studies demonstrate the overwhelming long-term costs involved when children grow up in the absence of appropriate nurturing. ${ }^{360}$

\section{Research Reform}

Major challenges have been raised regarding the quality and persuasiveness of the research touting DR as a success story. An increasing number of critics have given voice to their concerns both about the nature of the advocacy research and the substance of DR programs. ${ }^{361}$ This gives hope for better research in the future, providing a better guide to policymakers as to whether DR is the right direction for child welfare reform or, instead, just the wrong direction. It gives hope for research making child welfare the primary focus and research, honestly assessing the risks of DR, and also comparing DR not simply to the current, inadequate CPS system, but also to a strengthened CPS system with enhanced power to protect children.

But even if this hope is realized and even if the DR movement is brought to a halt, fundamental change in the dynamics of child welfare research is needed if history is not endlessly to repeat itself. We have now had many decades in which different forms of extreme family preservation have been promoted, supported by research designed simply to vindicate the ideological view of those promoting the policy programs. While there is some excellent independent research in the child welfare field, there is not nearly enough, and often it takes years for this research to surface, years during which advocacy programs are propagated based on false claims of success.

The child welfare field needs a new tradition of truly independent, neutral research, free from any advocacy agenda and committed to finding the objective truth. We need new sources for research funding that have no commitment to predetermined policy directions. We need social scientists to be able to pursue the truth and to ask questions and come to conclusions that challenge orthodox thinking, free from fear of retribution, including limits on future research opportunities. We need research that will place a new focus on child interests

360. See discussion supra Part V.B.; see also supra text accompanying note 350.

361. See supra Part IV.B.3. 
and that can provide a meaningful guide to policymakers interested in doing the right thing for children.

Without this kind of fundamental change in the field's research dynamics, we can predict that even if the DR reform movement is derailed, another similar movement will take its place and will enjoy years of success based largely on the same kind of self-serving research that has historically played such a harmful role.

\section{CONCLUSION}

DR represents a dangerous direction for children. But it is a familiar, dangerous direction. The dynamics that have produced this latest fad are the same dynamics that brought us the IFPS and Racial Disproportionality movements.

There is some indication now that this latest fad may be fading. One recent report lists nine states as having decided to eliminate or not expand their DR programs. ${ }^{362}$

Florida, one of the first states to adopt DR, dropped it after some five years of experience. ${ }^{363}$ Illinois recently dropped its DR program close to the end of the QIC-DR research study. ${ }^{364}$ The Illinois CPS Department justified this decision to the legislature based on concerns that DR had caused safety problems by diverting staff from the traditional CPS system, and it noted that the soon-to-be-released QIC-DR Report found children on the AR track more likely to experience maltreatment recurrence than children on the TR track. ${ }^{365}$ Michigan concluded that DR research provided insufficient support for the program and thus decided in 2013, and again in 2014, not to implement DR. ${ }^{366}$ In Los Angeles, a report by the County Counsel's Chil-

362. Piper, supra note 55, at 100. The Casey Family Programs Implementation Kit lists six states as having discontinued, with four of these in the planning stages of reinstating. GUTERMAN ET AL., supra note 7, at 6. The 2014 IOM Report mentions Arizona, Arkansas, and West Virginia as among those dropping their DR programs. IOM/NRC 2014 REPORT, supra note 2, at 199 .

363. Fla. Comm. on Children, Families, \& Elder AfFairs, Differential RESPONSE TO REPORTS OF CHILD ABUSE AND NEGLECT, S. 2011-105, at 3-4 (2010), available at http://www.flsenate.gov/UserContent/Session/2011/Publications/InterimReports/ pdf/2011-105cf.pdf, archived at http://perma.cc/D49U-DTQM (discussing 1998 legislation eliminating DR).

364. See FUlLeR ET AL., FINAL QIC-DR IL REPORT, supra note 2, at 93.

365. Letter from Denise Gonzales, Acting Director, Ill. Dep't. of Children \& Family Servs., to Sens. Mattie Hunter and Julie Morrison (Dec. 18, 2013) (on file with author).

366. Frank Vandervort, With Differential Response, History Repeats Itself and Children Are Placed at Unnecessary Risk, Chronicle OF Soc. CHANGE (July 8, 2014), https://chronicleofsocialchange.org/opinion/with-differential-response-history-repeats-itselfand-children-are-placed-at-unnecessary-risk/7422, archived at http://perma.cc/4LK5VKKW (noting as a veteran of family preservation systems in Michigan the similarity between that and DR, applauding Michigan's decision to reject DR after reviewing 15 research studies, but predicting that the powerful DR forces "[will] be back again" (emphasis added)); e-mail from Frank Vandervort, Clinical Professor of Law, Univ. of Mich. Law 
dren's Special Investigative Unit in 2012, triggered by a rash of child deaths, found that "under-informed investigations and an overreliance on L.A.'s differential response experiment . . . contributed to the majority of the deaths." ${ }^{67}$ Los Angeles eliminated its DR program in 2012 based on these and related concerns that the program's diversion of funds and staff from the traditional CPS system put children at undue risk. ${ }^{368}$ Minnesota, one of the early DR states, recently formed a taskforce to assess the dangers to children posed by the state's child welfare system, including its emphasis on DR and the related assignment of a large percentage of reported cases to the AR track. ${ }^{369}$

DR may be increasingly discredited and even derailed in the coming years. But we can expect DR to be followed by another similar movement. Radical change in the dynamics of the child welfare field and in our thinking about children's rights is a prerequisite for any true reform.

Sch., to Ronald Hughes, Executive Director, North American Resource Center for Child Welfare, Institute for Human Services, Judy Rycus Program Director, North American Resource Center for Child Welfare, Institute for Human Services, and author (May 26, 2014, 2:25 PM) (on file with author) (forwarding information about Michigan's DR program); see also Memorandum from Stacie Bladen, Mich. Dep't of Human Servs., to Steve Yager, Deputy Director, Mich. Dep't of Human Servs., Children's Servs. Administration (Mar. 31, 2014) (on file with author) (recommending against DR implementation in Michigan based on the priority that Michigan places on child safety, review of the research, and concern that DR's absence of investigation puts children at risk).

367. Heimpel, supra note 7.

368. Id.

369. See, e.g., Brandon Stahl, Task Force Assails Child Protection for Meager Follow-up, STAR TRIBUNE (Oct. 14, 2014, 6:17 AM), www.startribune.com/printarticle/?id=279047731, archived at http://perma.cc/TK6N-UUZT. 
